\title{
Fluorescence Resonance Energy Transfer Characterization of DNA Wrapping in Closed and Open Escherichia coli RNA Polymerase $-\lambda P_{R}$ Promoter Complexes
}

\author{
Raashi Sreenivasan ${ }^{\dagger, \ddagger}$, Sara Heitkamp ${ }^{\ddagger}$, Munish Chhabra ${ }^{\dagger, \ddagger}$, Ruth Saecker $^{\ddagger}$, Emily \\ Lingeman $\ddagger$, Mikaela Poulos $\ddagger$, Darrell McCaslin $\ddagger$, Michael W. Capp ${ }^{\ddagger}$, Irina Artsimovitch ${ }^{\|, \perp}$, \\ and $\mathbf{M}$. Thomas Record Jr. ${ }^{*},+,, \S$ \\ †Biophysics Program, University of Wisconsin-Madison, Madison, Wisconsin 53706, United \\ States \\ ‡Department of Biochemistry, University of Wisconsin—Madison, Madison, Wisconsin 53706, \\ United States \\ §Department of Chemistry, University of Wisconsin—Madison, Madison, Wisconsin 53706, United \\ States \\ "Department of Microbiology, The Ohio State University, Columbus, Ohio 43210, United States \\ ${ }^{\perp}$ Center for RNA Biology, The Ohio State University, Columbus, Ohio 43210, United States
}

\section{Abstract}

Initial recognition of promoter DNA by RNA polymerase (RNAP) is proposed to trigger a series of conformational changes beginning with bending and wrapping of the 40-50 bp of DNA immediately upstream of the -35 region. Kinetic studies demonstrated that the presence of upstream DNA facilitates bending and entry of the downstream duplex (to +20$)$ into the active site cleft to form an advanced closed complex (CC), prior to melting of $\sim 13 \mathrm{bp}(-11$ to +2$)$, including the transcription start site $(+1)$. Atomic force microscopy and footprinting revealed that the stable open complex (OC) is also highly wrapped $(-60$ to +20$)$. To test the proposed bent-wrapped model of duplex DNA in an advanced RNAP- $\lambda \mathrm{P}_{\mathrm{R}} \mathrm{CC}$ and compare wrapping in the $\mathrm{CC}$ and $\mathrm{OC}$, we use fluorescence resonance energy transfer (FRET) between cyanine dyes at far-upstream $(-100)$ and downstream $(+14)$ positions of promoter DNA. Similarly large intrinsic FRET efficiencies are observed for the CC $(0.30 \pm 0.07)$ and the OC $(0.32 \pm 0.11)$ for both probe orientations. Fluorescence enhancements at +14 are observed in the single-dye-labeled CC and OC. These results demonstrate that upstream DNA is extensively wrapped and the start site region is bent into the cleft in the advanced CC, reducing the distance between positions -100 and +14 on promoter DNA from $>300$ to $<100 \AA$. The proximity of upstream DNA to the downstream cleft in the

\footnotetext{
*Corresponding Author: Department of Biochemistry, University of Wisconsin—Madison, Madison, WI 53706. mtrecord@wisc.edu. Phone: (608) 262-5332.

Supporting Information

The Supporting Information is available free of charge on the ACS Publications website at DOI: 10.1021/acs.biochem.6b00125. DNA sequence, methods of preparation of DNAs, and Figures S1-S9 (PDF)

Notes

The authors declare no competing financial interest.
} 
advanced $\mathrm{CC}$ is consistent with the proposed mechanism for facilitation of $\mathrm{OC}$ formation by upstream DNA.

\section{Graphical abstract}

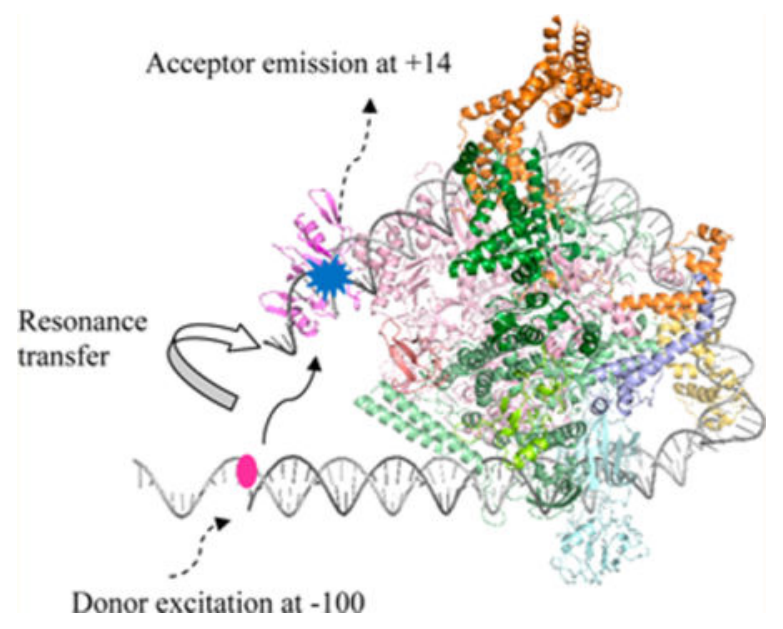

Efficient conversion of closed promoter complexes (generically called CC) to open complexes (generically OC) requires interactions of RNA polymerase (RNAP) with upstream and downstream DNA as well as with the central recognition region from the -35 element to the transcription start site $(+1) .{ }^{1,2}$ Interactions of RNAP with the 20 bp region downstream of +1 are key players in the conversion of the initial unstable OC to the more stable OC. ${ }^{3-5}$ Interactions of RNAP with $40-50$ bp of DNA upstream of the -35 element, including the region of the UP element and far-upstream DNA, are necessary for rapid isomerization of the $\mathrm{CC}$ to the $\mathrm{OC}$. Truncations in this upstream region reduce isomerization rates of lacUV5 and $\lambda \mathrm{P}_{\mathrm{R}}$ promoters by up to 2 orders of magnitude. ${ }^{6-8}$

How do upstream and downstream DNA exert these effects? Formation of the initial CC (often called $\mathrm{RP}_{\mathrm{c}}$ or $\mathrm{RP}_{\mathrm{c} 1}$ ) in which the promoter DNA is presumed to be linear and interactions with RNAP extend downstream only to the discriminator region $(-7 \text { to }-2)^{9-11}$ sets in motion a series of conformational changes in RNAP and promoter DNA. $1,2,7,8,12-14$ To explain the large decrease in the isomerization rate during $\mathrm{OC}$ formation that results from the truncation of upstream DNA, as well as the features observed in real-time footprints of $\mathrm{CC}$ at full-length and truncated promoter DNA, ${ }^{8}$ we proposed that bending and wrapping of the UP element region and far-upstream DNA on RNAP are among the first of these large conformational changes. ${ }^{1,7}$

Wrapping of upstream DNA around RNAP brings it near the $a$ NTD (which act as hinges at the base of the active site cleft) and also near the downstream cleft, triggering conformational changes in the cleft and in downstream mobile elements (DMEs) of RNAP at the $\lambda \mathrm{P}_{\mathrm{R}}$ promoter. ${ }^{1,4,12}$ These conformational changes facilitate bending of the downstream duplex into the cleft to form the most advanced $\mathrm{CC}$ prior to opening, in which more than 100 bp of promoter DNA $(-82$ to +20$)$ interacts with RNAP. ${ }^{1,2,4,7}$ The first kinetically significant intermediate (previously designated $\mathrm{I}_{1}$ ) formed at the full-length $\lambda \mathrm{P}_{\mathrm{R}}$ 
promoter is a population of advanced CC. ${ }^{7,8,14}$ Subsequent isomerization of $\mathrm{I}_{1}$ was shown to involve DNA opening in the cleft by RNAP, forming the initial OC (a kinetically significant intermediate in the dissociation at $\lambda \mathrm{P}_{\mathrm{R}}$ promoter, designated $\left.\mathrm{I}_{2}\right) .{ }^{15}$ At many promoters, after opening, rearrangements of the nontemplate strand in the cleft and of DME of RNAP that assemble on the downstream duplex rapidly convert the initial OC to a more stable OC. ${ }^{4,5} \mathrm{At}$ $\lambda \mathrm{P}_{\mathrm{R}}$, this rapid stabilization of $\mathrm{I}_{2}$ occurs in several steps, with an additional, more advanced open intermediate (designated $\mathrm{I}_{3}$, which is kinetically significant during dissociation) ${ }^{16}$ on the pathway to formation of the most stable OC (designated $\mathrm{RP}_{\mathrm{O}}$ at $\lambda \mathrm{P}_{\mathrm{R}}$ ). ${ }^{4,5}$ In this work, the advanced $\lambda \mathrm{P}_{\mathrm{R}}$ closed complex investigated (designated $\mathrm{CC}$ ) is that formed at equilibrium at temperatures below the opening transition (i.e., $0-5{ }^{\circ} \mathrm{C}$ ). ${ }^{12,14,17}$ This is a $\mathrm{RP}_{\mathrm{c} 2}$-like complex ${ }^{18}$ analogous to the kinetic intermediate $\mathrm{I}_{1} \cdot{ }^{7,12}$ The $\lambda \mathrm{P}_{\mathrm{R}}$ open complex investigated (designated OC) is that formed at $19{ }^{\circ} \mathrm{C}$ (presumably largely $\mathrm{RP}_{\mathrm{O}}$ ). ${ }^{12,17}$

While far-upstream ( -65 to -82$)$ interactions are eliminated in conversion of the advanced $\mathrm{CC}$ to the stable $\lambda \mathrm{P}_{\mathrm{R}} \mathrm{OC}$, footprinting reveals that at least $80 \mathrm{bp}(-65$ to +20$)$ of $\lambda \mathrm{P}_{\mathrm{R}}$ promoter DNA remains in tight contact with RNAP, ${ }^{7}$ twice the length of the DNA contacted in the elongation complex (40 bp; -20 to +20$).{ }^{19}$ AFM DNA compaction studies reveal that the $\lambda \mathrm{P}_{\mathrm{R}}$ promoter DNA is wrapped around RNAP in stable OC, ${ }^{20,21}$ and also in abortively initiating complexes. ${ }^{22}$ Hence, evidence of extensive bending and wrapping of promoter DNA in both advanced $\lambda \mathrm{P}_{\mathrm{R}} \mathrm{CC}$ and $\mathrm{OC}$ exists. Unwrapping must occur during or before promoter escape.

Bending and/or wrapping of DNA appear to be general properties of the $\mathrm{CC}$ and $\mathrm{OC}$ at other bacterial promoters and for eukaryotic RNAP. Extensive bending and wrapping of TyrT promoter DNA in a CC with RNAP were observed by AFM. ${ }^{23}$ Transcription factors such as FIS and CAP bind to upstream DNA in the region of the UP element ( -40 and -60$)$, bending $(\mathrm{CAP})^{24}$ and wrapping (FIS) ${ }^{23,25}$ promoter DNA in the CC. Members of the metaldependent MerR family of transcriptional regulators that recognize the spacer region of promoter DNA convert the early CC formed in the repressed (apo or metal-free) state, in which the -10 region is not contacted, ${ }^{26-28}$ to an activated state upon metal binding that unwinds and bends this region to contact $\sigma$ region 2 in a more advanced $\mathrm{CC}^{27}$ Extensive wrapping of promoter DNA in CC formed by eukaryotic RNA Pol II was also observed by cross-linking and electron microscopy. ${ }^{29-31}$ Evidence of wrapping in the OC at other bacterial promoters has emerged from footprinting, 9,32 supercoiling assays, ${ }^{33}$ and gel shift assays. ${ }^{34}$ To date, however, no direct spectroscopic assay for investigating structural, thermodynamic, and kinetic-mechanistic aspects of promoter bending and wrapping has been reported. Here we use ensemble Förster (fluorescence) resonance energy transfer (FRET) from Cy3 to Cy5 cyanine dyes attached at the upstream (-100) and downstream $(+14)$ ends of $\lambda P_{R}$ promoter duplexes as a quantitative assay for the large reduction in the end-to-end distance of promoter DNA anticipated from bending and wrapping in both the $\mathrm{CC}$ and the OC. We also use RNAP-induced cyanine dye fluorescence enhancements often called PIFE effects ${ }^{35-41}$ at +14 to monitor the proximity of the +14 position of promoter DNA to RNAP in closed and open complexes. In ongoing research, we are applying these FRET and PIFE assays in fast kinetic studies of the roles of promoter bending and wrapping in the mechanism of formation and advancement of the initial $\mathrm{CC}$, the isomerization to the 
initial OC, and the subsequent stabilization of the OC by in-cleft and downstream conformational changes.

\section{MATERIALS AND METHODS}

\section{Buffers}

Storage buffer (SB) for the RNAP holoenzyme consists of 50\% (v/v) glycerol, $10 \mathrm{mM}$ Tris (pH 7.5 at $4{ }^{\circ} \mathrm{C}$ ), $100 \mathrm{mM} \mathrm{NaCl}, 0.1 \mathrm{mM}$ dithiothreitol (DTT), and $0.1 \mathrm{mM} \mathrm{Na}_{2}$ EDTA. Annealing buffer $(\mathrm{AB})$ consists of $0.1 \mathrm{M}$ potassium glutamate, $25 \mathrm{mM}$ Tris-acetate (pH 7.6), and $10 \mathrm{mM}$ magnesium acetate ("KGB buffer"). ${ }^{42,43}$ Buffer for FRET experiments (FB) consists of $40 \mathrm{mM}$ Tris (pH 8), $10 \mathrm{mM} \mathrm{MgCl} 2,120 \mathrm{mM} \mathrm{KCl}, 0.05 \mathrm{mg} / \mathrm{mL}$ BSA, $1 \mathrm{mM}$ DTT, and $0.02 \%$ Tween. Buffer for transcription assays (TB) consists of $40 \mathrm{mM}$ Tris (pH 8), $5 \mathrm{mM} \mathrm{MgCl}_{2}, 60 \mathrm{mM} \mathrm{KCl}, 0.1 \mathrm{mg} / \mathrm{mL}$ BSA, and $1 \mathrm{mM}$ DTT. Quench dye buffer (QB) for transcription assays consists of TB with $8 \mathrm{M}$ urea, $15 \mathrm{mM} \mathrm{Na}_{2} \mathrm{EDTA}, 0.05 \%$ (w/v) xylene cyanol, and $0.05 \%(\mathrm{w} / \mathrm{v})$ bromophenol blue. Stop solution for permanganate foot-printing consists of $1 \mathrm{M} \beta$-mercaptoethanol and $2.6 \mathrm{M}$ ammonium acetate. Unless specified, all reagents were from Sigma-Aldrich (St. Louis, MO).

\section{RNA Polymerase}

Wild-type Escherichia coli RNAP core $\left(\alpha_{2} \beta \beta^{\prime} \omega\right)$ was overexpressed in E. coli BL21( $\lambda$ DE3) cells from plasmid pVS10 and purified using standard protocols. ${ }^{44} \sigma^{70}$ was overexpressed in E. coli strain M5219 containing plasmid pMRG8 and purified as previously described. ${ }^{45}$ RNAP holoenzyme was reconstituted by incubating $5 \mu \mathrm{M}$ core RNAP with a 2-fold molar excess of purified $\sigma^{70}$ for $1 \mathrm{~h}$ at $37{ }^{\circ} \mathrm{C}$. Holoenzyme was stored at $-20{ }^{\circ} \mathrm{C}$ for short-term use. Different preparations of reconstituted RNAP were 70-100\% active in OC formation.

\section{Preparation of Cy3- and/or Cy5-Labeled $\lambda P_{R}$ Promoter and Cy3(+14)-Cy5(-100) Control DNA}

Single-dye-labeled $\lambda \mathrm{P}_{\mathrm{R}}\left[\mathrm{Cy} 3(+14)\right.$ or Cy5(+14) $\lambda \mathrm{P}_{\mathrm{R}}$ and Cy3(-100) or Cy5(-100) $\left.\lambda \mathrm{P}_{\mathrm{R}}\right]$, two-dye-labeled $\lambda \mathrm{P}_{\mathrm{R}}\left[\mathrm{Cy} 3(-100)-\mathrm{Cy} 5(+14)\right.$ or Cy3(+14)-Cy5(-100) $\left.\lambda \mathrm{P}_{\mathrm{R}}\right]$, and two-dyelabeled nonpromoter DNA [Cy3(+14)-Cy5(-100) nonpromoter DNA] as a control for FRET experiments were prepared from dye-labeled primers using the sequences and methods described in the Supporting Information.

\section{Steady-State FRET and PIFE Fluorescence Methods}

RNAP-promoter complexes were formed by incubating $100 \mathrm{nM} \mathrm{Cy3-Cy5} \lambda \mathrm{P}_{\mathrm{R}}$ DNA and 20-120 nM RNAP for 20-90 min in FB at $2{ }^{\circ} \mathrm{C}$ (for CC) or $19{ }^{\circ} \mathrm{C}$ (for OC). ${ }^{12,17}$ No differences were observed between complexes incubated for these different times. FRET experiments with dye-labeled OC were performed at $19{ }^{\circ} \mathrm{C}$ because the fluorescence emission intensity of cyanine dyes decreases strongly with an increase in temperature (see also Figure S4) ${ }^{46}$ Parallel series of experiments were performed with singly and doubly labeled $100 \mathrm{nM}$ (Cy3, Cy5) promoter DNA. A Quantamaster C-60/2000 spectrofluorimeter (Photon Technology Instruments) equipped with a $75 \mathrm{~W}$ xenon compact arc lamp and single monochromators on the excitation and emission beam path was used for all experiments. Cuvettes were coated with Sigmacote before each experiment. Excitation and emission slit 
widths were 3 and $5 \mathrm{~nm}$, respectively. Samples were excited at $515 \mathrm{~nm}$ (for Cy3) or at 610 $\mathrm{nm}$ (for Cy5); these wavelengths were chosen to minimize direct excitation of Cy5 from excitation of $\mathrm{Cy} 3$ and to minimize overlap of Cy5 excitation and emission spectra. Emission spectra were collected between 550 and $720 \mathrm{~nm}$ for two-dye FRET experiments and for single-dye Cy 3 experiments and between 620 and $720 \mathrm{~nm}$ for single-dye Cy5 experiments. Samples were removed from the instrument or shuttered when not being observed to minimize photodamage. For the temperature series experiment (Figure S4), the temperature was increased in steps and the cuvette equilibrated at each temperature before the emission scan.

\section{Steady-State Fluorescence Anisotropy (FA) Methods}

Anisotropy measurements were performed with a Quanta-master C-60/2000 spectrofluorimeter (Photon Technology Instruments) equipped with two polarizers in the paths for excitation and emission using the L-format method. Experimental settings were as in the FRET and PIFE experiments. Intensity values, I, were recorded over $120 \mathrm{~s}$ at $565 \mathrm{~nm}$ for $\mathrm{Cy} 3$ and $660 \mathrm{~nm}$ for Cy5 ( $\lambda_{\max }^{\mathrm{em}}$ as determined from FRET and PIFE experiments). Anisotropy $r$ was calculated as ${ }^{47,48}$

$$
r=\frac{I_{\|}-G I_{\perp}}{I_{\|}-2 G I_{\perp}}
$$

The subscripts on $I$ indicate the relative orientations (parallel and perpendicular) of the excitation and emission polarizers. $G$, the instrumental correction factor for different detection sensitivities for vertically and horizontally polarized light, was measured with Cy3- and Cy5-labeled primers separately. Individual values of $\mathrm{I}_{\|}$and $I_{\perp}$ used to calculate $r$ from eq 1 were determined by averaging data from two scans in each determination. Values of $r$ at 19 and $2{ }^{\circ} \mathrm{C}$ reported here are averages of three and two independent determinations, respectively. Uncertainties are reported as deviations from the average.

Predicted anisotropy $r$ of the dye that is immobilized on DNA in the CC and OC and moves with only the entire dye-DNA-RNAP complex is estimated to be 0.4 (the maximal anisotropy) from the Perrin equation, ${ }^{47}$ using Cy3 and Cy5 fluorescence lifetimes ( $\tau \sim 2 \mathrm{~ns}$ ) and a characteristic time for rotational diffusion of the RNAP-DNA CC and OC modeled as spheres $\left(1 / D_{\mathrm{r}} \approx 700 \mathrm{~ns},{ }^{49}\right.$ where $D_{\mathrm{r}}$ is the rotational diffusion coefficient). Because $\tau \ll$ $1 / D_{\mathrm{r}}$, the DNA-RNAP complex does not reorient significantly on the time scale of the fluorescence lifetime.

\section{Calculation and Analysis of FRET Efficiency}

FRET efficiency $E$ was calculated from the emission of the acceptor (Cy5) by the "Ratio ${ }_{\mathrm{A}}$ " method. ${ }^{47,50,51}$ For a CC or OC between Cy3-Cy5 labeled DNA and RNAP, Ratio ${ }_{\mathrm{A}}$ at Cy5 $\lambda_{\max }^{\mathrm{em}}(660 \mathrm{~nm})$

$$
\text { Ratio }_{\mathrm{A}, 660 \mathrm{~nm}}=\frac{I_{660 \mathrm{~nm}}^{\text {Cy3exc }}}{I_{660 \mathrm{~nm}}^{\text {Cy5exc }}}
$$


where $I_{660 \mathrm{~nm}}^{\mathrm{Cy} 3 \mathrm{exc}}$ is the Cy5 emission intensity obtained by Cy3 excitation at $515 \mathrm{~nm}$ and $I_{660 \mathrm{~nm}}^{\mathrm{Cy} 5 \mathrm{exc}}$ is the Cy5 emission intensity obtained by direct Cy5 excitation at $610 \mathrm{~nm}$. For this calculation, the Cy5 portion of the emission spectrum for excitation of $\mathrm{Cy} 3-\mathrm{Cy} 5$ labeled DNA (at $515 \mathrm{~nm}$ ) was determined by subtracting a reference spectrum obtained for Cy3 DNA (Figure S7). Prior to subtraction, this reference spectrum was normalized to match the fluorescence intensity of the Cy3-Cy5 labeled DNA-RNAP spectra over the wavelength range where only $\mathrm{Cy} 3$ emits $(555-570 \mathrm{~nm})$.

Analysis of Ratio $_{\mathrm{A}}$ yields FRET efficiency $E$ from eq $3:^{50,51}$

$$
\text { Ratio }_{\mathrm{A}, 660 \mathrm{~nm}}=E \frac{\varepsilon_{\mathrm{Cy} 3}^{515 \mathrm{~nm}}}{\varepsilon_{\mathrm{Cy} 5}^{610 \mathrm{~nm}}}+\frac{\varepsilon_{\mathrm{Cy} 5}^{515 \mathrm{~nm}}}{\varepsilon_{\mathrm{Cy} 5}^{610 \mathrm{~nm}}}
$$

applicable when the same wavelength (here $660 \mathrm{~nm}$ ) is used to measure acceptor emission from donor excitation (FRET) and from direct excitation of the acceptor. ${ }^{50,51}$ Extinction coefficients $(\varepsilon)$ for Cy3 and Cy5 in the dye-labeled DNA at the excitation wavelengths used (515 $\mathrm{nm}$ for $\mathrm{Cy} 3$ and 515 and $610 \mathrm{~nm}$ for Cy5) were determined using variable-path-length technology (SoloVPE system from C Technologies). The absorbance of the Cy3- or Cy5labeled DNA at a known concentration was measured for at least 10 different path lengths from 0.25 to $5 \mathrm{~mm}$, from which $\varepsilon_{\mathrm{Cy} 5}^{610 \mathrm{~nm}}, \varepsilon_{\mathrm{Cy} 5}^{515 \mathrm{~nm}}$, and $\varepsilon_{\mathrm{Cy} 5}^{515 \mathrm{~nm}}$ were determined. ${ }^{47}$ Values obtained $\left(\varepsilon_{\mathrm{Cy} 5}^{610 \mathrm{~nm}}=9.3 \times 10^{4} \mathrm{M}^{-1} \mathrm{~cm}^{-1} ; \varepsilon_{\mathrm{Cy} 5}^{515 \mathrm{~nm}}=5.6 \times 10^{3} \mathrm{M}^{-1} \mathrm{~cm}^{-1}\right.$; $\varepsilon_{\mathrm{Cy} 5}^{515 \mathrm{~nm}}=9.6 \times 10^{4} \mathrm{M}^{-1} \mathrm{~cm}^{-1}$ ) are consistent with previously published values at other wavelengths when converted using the spectra of these dyes. ${ }^{52}$

Values of $E$ reported here have been corrected for the population fraction of free promoter DNA at each concentration of RNAP investigated. For the $\mathrm{CC}$ and $\mathrm{OC}$ formed by Cy3(-100)-Cy5(+14) $\lambda \mathrm{P}_{\mathrm{R}}$ DNA, Cy5(+14) PIFE is observed to make a $30 \%$ contribution (occupancy-corrected) to both the numerator and the denominator of eq 1 for Ratio $\mathrm{A}$ and has no net effect on the calculation of the FRET $E$. For the $\mathrm{CC}$ and $\mathrm{OC}$ formed by $\mathrm{Cy} 3(+14)-$ Cy5(-100) $\lambda \mathrm{P}_{\mathrm{R}}, \mathrm{Cy} 3(+14) \mathrm{PIFE}$ is observed to make a $20 \%$ contribution (occupancycorrected) to the numerator of Ratio $_{\mathrm{A}}$ and is accounted for in calculating Ratio ${ }_{\mathrm{A}}$.

Interdye distance $R$ is calculated from efficiency $E$ :

$$
R=R_{\mathrm{o}}\left(E^{-1}-1\right)^{1 / 6}
$$

where the Förster distance, $R_{\mathrm{O}}$, is the distance at which $E=0.5$ for the Cy3-Cy5 pair and is given by ${ }^{47}$

$$
R_{\mathrm{O}}=\left(9.78 \times 10^{3}\right)\left[\boldsymbol{\Phi}_{\mathrm{D}} \kappa^{2} \eta^{-4} J(\nu)\right]^{1 / 6} \AA
$$

In eq 4 , refractive index $\eta=1.33$, the spectral overlap integral for Cy3 and Cy5 is $J(v)=7.2$ $\times 10^{-13} \mathrm{M}^{-1} \mathrm{~cm}^{3},{ }^{53} \Phi_{\mathrm{D}}$ is the quantum yield of $\mathrm{Cy} 3$, and $\kappa^{2}$ is the orientation factor (see below). 
The quantum yield of donor $\mathrm{Cy} 3\left(\Phi_{\mathrm{D}}\right)$ depends on temperature and on its environment, including attachment to single-stranded DNA (ssDNA) or double-stranded DNA (dsDNA). ${ }^{46}$ For cyanine dyes attached at position +14 , RNAP (protein)-induced fluorescence enhancement (often called PIFE) ${ }^{35,36}$ contributes to the quantum yield and hence the emission intensity. In our dye-labeled DNA, Cy3 or Cy5 is inserted between position $5^{\prime}$ of the end deoxyribose of dsDNA and position $3^{\prime}$ of the first deoxyribose in a short ss region at the end of the duplex (see the Supporting Information). Correcting for PIFE effects by short extrapolation of a linear fit of Cy3-5 dsDNA $\Phi_{\mathrm{D}}$ versus temperature ${ }^{46}$ to $2^{\circ} \mathrm{C}$ gives a $\Phi_{\mathrm{D}}$ of $0.34 \pm 0.03$ and by interpolation a $\Phi_{\mathrm{D}}$ of $0.21 \pm 0.02$ at $19^{\circ} \mathrm{C}$, when $\mathrm{Cy} 3$ is at +14 .

Similarly, $\Phi_{\mathrm{D}}=0.31 \pm 0.03$ at $2{ }^{\circ} \mathrm{C}$ and $\Phi_{\mathrm{D}}=0.19 \pm 0.02$ at $19{ }^{\circ} \mathrm{C}$ when $\mathrm{Cy} 3$ is at -100 . These results are applicable at the salt concentrations used in our experiments. ${ }^{46}$

Minimal and maximal values of orientation factor $k^{2}$ for our DNA-RNAP complexes were estimated from anisotropy measurements of donor and acceptor dyes $\left(r_{\mathrm{a}}\right.$ and $\left.r_{\mathrm{d}}\right)$ using eqs 6 and $7: 47,54$

$$
\begin{gathered}
\kappa_{\min }^{2} \approx \frac{2}{3}\left(1-\frac{\sqrt{\frac{5 r_{\mathrm{d}}}{2}}+\sqrt{\frac{5 r_{\mathrm{a}}}{2}}}{2}\right) \\
\kappa_{\max }{ }^{2} \approx \frac{2}{3}\left(1+\sqrt{\frac{5 r_{\mathrm{d}}}{2}}+\sqrt{\frac{5 r_{\mathrm{a}}}{2}}+3 \sqrt{\frac{5 r_{\mathrm{d}}}{2}} \sqrt{\frac{5 r_{\mathrm{a}}}{2}}\right)
\end{gathered}
$$

where $r_{\mathrm{d}}$ and $r_{\mathrm{a}}$ are the emission anisotropy of the donor and acceptor, respectively, measured at $\lambda_{\max }^{\mathrm{em}}$ and the factor $5 / 2=1 / r_{\max }$, where $r_{\max }$ is the maximal anisotropy obtained for an immobilized dye. ${ }^{47}$ Together, eqs 6 and 7 determine a range of $\kappa^{2}$ values bracketing $\kappa^{2}=2 / 3$. Both $\kappa_{\min }{ }^{2}$ and $\kappa_{\max }{ }^{2}$ approach $2 / 3$ as $r$ approaches zero (the random orientation situation) and diverge to define a wider range of possible $k^{2}$ values, approaching $0 \leq \mathrm{K}^{2} \leq 4$ as $r_{\mathrm{a}}$ and $r_{\mathrm{d}}$ increase to 0.4 (the immobilized dye anisotropy).

\section{Permanganate Footprinting Assay}

Permanganate foot-printing was performed to characterize the position and extent of opening of promoter DNA in a dye-labeled DNA ${ }^{55}$ (see the Supporting Information). ${ }^{32} \mathrm{P}$ end labeling of dye-labeled primers was unsuccessful, and permanganate footprinting was therefore performed only for Cy5 $(-100)$ or Cy $3(-100) \lambda \mathrm{P}_{\mathrm{R}}$ where the upstream primer had an internal Cy5 or Cy3 while the downstream primer with no dye (Down primer) was endlabeled with $\left[\gamma^{32} \mathrm{P}\right]$ ATP with T4 polynucleotide kinase (PNK) (NEB, Ipswich, MA). The $\mathrm{MnO}_{4}{ }^{-}$reference was ${ }^{32} \mathrm{P}$-labeled $\lambda \mathrm{P}_{\mathrm{R}}$ without any fluorescent probe. DNA was purified as indicated above. DNA-RNAP complexes were formed in FB using $\sim 1 \mathrm{nM}$ promoter DNA and $\sim 80 \mathrm{nM}$ RNAP on ice $\left(0{ }^{\circ} \mathrm{C}\right.$; $\left.\mathrm{CC}\right)$ and at $19{ }^{\circ} \mathrm{C}(\mathrm{OC})$ for $\sim 60 \mathrm{~min} . \mathrm{KMnO}_{4}$ was added to a final concentration of $10 \mathrm{mM}$ and the reaction conducted for $10 \mathrm{~s}$ at $19{ }^{\circ} \mathrm{C}$ and for $60 \mathrm{~s}$ on ice $\left(0{ }^{\circ} \mathrm{C}\right)$. Subsequent workup was performed as described previously. ${ }^{4}$ Footprinting gels were imaged using a Typhoon FLA-9000 instrument (GE Healthcare Biosciences, Pittsburgh, PA) and analyzed using Image Quant TL. Band intensity analyses were performed with ImageJ. ${ }^{56}$ 


\section{Transcription Assay}

To form OC, solutions containing $100 \mathrm{nM} \lambda \mathrm{P}_{\mathrm{R}}$ promoter DNA and $80 \mathrm{nM}$ RNAP were incubated as described above. Transcription was initiated with $50 \mu \mathrm{M}$ ATP, CTP, and GTP and $170 \mathrm{nM} / 10 \mu \mathrm{Ci}\left[\alpha^{-32} \mathrm{P}\right] \mathrm{UTP}$. Samples were incubated for $10 \mathrm{~min}$ at $19^{\circ} \mathrm{C}$ after the addition of $\left[a^{3}{ }^{32} \mathrm{P}\right] \mathrm{UTP}$. QB was then added to the samples that were heated to $90{ }^{\circ} \mathrm{C}$ for 2 min. Samples were centrifuged and loaded on a $8 \mathrm{M}$ urea, $20 \%$ denaturing acrylamide gel along with a 10-100-nucleotide low-molecular weight RNA ladder from USB-Affymetrix (Santa Clara, CA) end-labeled with $\left[\gamma^{32}\right.$ P]ATP by T4 PNK. Transcription gels were imaged using a Typhoon FLA-9000 instrument, and line scans were analyzed using Image Quant TL or ImageJ. ${ }^{56}$

\section{Construction of Models of RNAP-Promoter Complexes}

Models of the RNAP-promoter CC and OC were made and manipulated using PyMOL Molecular Graphics System, version 1.7.0.3 (Schrödinger LLC, New York, NY), and Coot. ${ }^{57}$ For the CC, our starting point was the published model of a wrapped $\mathrm{CC},{ }^{7}$ which predated the E. coli RNAP structures and was therefore based on the Thermus thermophilus RNAP structure. The distance $R$ between backbone (probe) positions at positions -100 to +14 in the original model is $85 \AA$. To update this CC model, we replaced T. thermophilus RNAP with E. coli RNAP [Protein Data Bank (PDB) entry 4LJZ], ${ }^{58}$ which did not affect the distance between -100 and +14 . We then used the previously described approach to refine this initial model to reduce the distance between -100 and +14 and to match the published footprinting data. ${ }^{7}$ We modeled the $a \mathrm{CTD}$ by analogy to the published wrapped CC model $^{7}$ using PDB structure $1 \mathrm{LB} 2$ for the $a \mathrm{CTD}^{59}$ and centering them at UP element positions -42 and -52 . Key residue R265 is placed in the minor groove, and the acidic patch on the proximal $a$ CTD (D259 and E261) is aligned with R603 on $\sigma$ region $4 .{ }^{60}$

No molecular model for bent, wrapped upstream DNA in an OC is available. To construct an OC model, we used the recent structure of the E. coli RNAP transcription initiation complex (PDB entry 4YLN). ${ }^{61}$ In this structure, the promoter DNA is open from -11 to +4 and surrounding duplex DNA extends from -37 to +13 . We modeled the $a$ CTD (1LB2) as in the CC model. Upstream DNA ( -38 to approximately -112 ) was bent and wrapped on this structure as in the $\mathrm{CC}$ model described above, to be consistent with $\mathrm{OC} \mathrm{HO}^{\bullet}$ footprinting data. $^{7}$

\section{RESULTS}

\section{Large Cy5 FRET Acceptor Signals from Exciting Cy3 Demonstrate DNA Wrapping in Advanced Closed and Open RNAP- $\lambda P_{\mathbf{R}}$ Promoter Complexes}

As a direct spectroscopic test of the proposed model of DNA bending and wrapping in the advanced $\mathrm{CC}^{7}$ and to compare extents of DNA wrapping in the advanced $\mathrm{CC}$ and $\mathrm{OC}$, a far upstream $(-100)$ position on the nontemplate strand backbone and a downstream $(+14)$ position on the template strand backbone of a $\lambda \mathrm{P}_{\mathrm{R}}$ promoter DNA fragment were internally labeled with the $\mathrm{Cy} 3 / \mathrm{Cy} 5$ donor/acceptor pair of cyanine dyes. Previous DNaseI footprinting ${ }^{14}$ revealed that the equilibrium $0{ }^{\circ} \mathrm{C} \mathrm{RNAP}-\lambda \mathrm{P}_{\mathrm{R}}$ complex, like the intermediate characterized in real time at a higher temperature, ${ }^{7}$ is an advanced $\mathrm{CC}$ with the downstream 
duplex protected to +20 by interactions with RNAP. Far-upstream contacts in the $0{ }^{\circ} \mathrm{C}$ complex could not be characterized by footprinting because of the low DNaseI reactivity of this region of this promoter DNA. Here we investigate FRET between cyanine dyes at positions -100 and +14 in the advanced $2{ }^{\circ} \mathrm{C} \lambda \mathrm{P}_{\mathrm{R}} \mathrm{CC}$ and compare it with results for the stable $19^{\circ} \mathrm{C} \lambda \mathrm{P}_{\mathrm{R}} \mathrm{OC}\left(\mathrm{RP}_{\mathrm{o}}\right)$ and with the fluorescence behavior of a nonpromoter Cy3-Cy5 labeled DNA fragment.

The signature of FRET is emission from the acceptor dye (Cy5) centered at its emission maximum, upon excitation of the donor (Cy3) in a two-dye construct. Figure 1 shows Cy5 emission spectra as a function of Cy3-Cy5 promoter DNA (100 nM) in complex with RNAP for both orientations of the FRET pair of $\mathrm{Cy} 3$ and Cy5 dyes -100 and +14 in the advanced $\lambda \mathrm{P}_{\mathrm{R}}$ CC. Figure 2 shows the analogous series of Cy5 emission spectra for the stable $\lambda \mathrm{P}_{\mathrm{R}} \mathrm{OC}$. A very significant FRET effect is demonstrated in both Figures 1 and 2 by the increases in Cy5 emission $\left(\lambda_{\mathrm{em}}^{\max }=660 \mathrm{~nm}\right)$ with an increasing RNAP:promoter DNA concentration ratio up to approximately $0.6-0.8: 1$. (Additional series of titrations showing FRET for both the $\mathrm{CC}$ and the $\mathrm{OC}$ for both orientations of $\mathrm{Cy} 3$ and $\mathrm{Cy} 5$ are shown in Figure S2). In all cases, the excitation wavelength is $515 \mathrm{~nm}$, near the $\mathrm{Cy} 3$ excitation maximum and a wavelength at which direct excitation of Cy5 is minimized.

Observation of FRET unambiguously demonstrates extensive bending and wrapping of promoter DNA on RNAP in both the CC and the OC, reducing the separation distance between -100 and +14 of the DNA backbone in both complexes from $>300 \AA$ on free DNA (a slightly flexible cylinder) to $<100 \AA$ (the upper bound distance ${ }^{47}$ for detecting a FRET effect). These results provide the first spectroscopic demonstration of large-scale bending and wrapping in any closed or open RNAP-promoter DNA complex. No FRET is observed at either 2 or $19{ }^{\circ} \mathrm{C}$ for a 1:1 mixture of RNAP $(100 \mathrm{nM})$ and an analogous Cy3-Cy5 labeled nonpromoter DNA (100 nM), lacking the $-10,-35$, and UP element sequences of the $\lambda P_{R}$ promoter (Figure S3; see the Supporting Information for sequence information). This demonstrates that the FRET effect, and DNA bending and wrapping by RNAP, are properties of the promoter CC and OC and not due to the dyes and DNA ends.

At RNAP:promoter DNA concentration ratios of 0.6-0.8:1, the FRET effect plateaus. In some cases, the FRET effect is reduced upon further titration with RNAP, perhaps indicating competition from weaker end binding modes of RNAP. Fluorescence intensities are significantly higher for both dyes at $2{ }^{\circ} \mathrm{C}$ than at $19^{\circ} \mathrm{C}$ (Figures 1 and 2), as expected because of the reduction in quantum yield with increasing temperature for cyanine dyes (Figure S4) ${ }^{46}$ Because of this, OC FRET measurements were made at $19^{\circ} \mathrm{C}$ instead of $37^{\circ} \mathrm{C}$. Because $19^{\circ} \mathrm{C}$ is well above the opening transition range $\left(5-15^{\circ} \mathrm{C}\right)$ for the $\lambda \mathrm{P}_{\mathrm{R}}$ promoter, ${ }^{12,17}$ all complexes are OCs at $19{ }^{\circ} \mathrm{C}$.

For the two-dye-labeled promoter complexes, Figure 3 plots the acceptor:donor emission intensity ratio $I_{\mathrm{Cy} 5} / I_{\mathrm{Cy} 3}$ as a function of RNAP:promoter DNA concentration ratio for both locations of the probes and both temperatures investigated. This analysis shows that $I_{\mathrm{Cy} 5} /$ $I_{\mathrm{Cy} 3}$ increases monotonically and linearly with an increasing RNAP:promoter DNA concentration ratio to a plateau value attained at a ratio of 0.6-0.8:1, completely consistent with the behavior of the Cy5 acceptor signal in Figures 1 and 2. The linearity of the plots in 
Figure 3 demonstrates complete binding of the limiting reagent (RNAP) for all RNAP:promoter DNA concentration ratios of $<1: 1$ for the concentrations of these experiments (100 nM promoter DNA). The data in these figures and Figures S1 and S2 provide the information needed to calculate FRET efficiencies and estimate distances between far-upstream $(-100)$ and downstream $(+14)$ positions of promoter DNA in the wrapped $\mathrm{CC}$ and $\mathrm{OC}$.

\section{Calculation of FRET Efficiencies and Implications for DNA Wrapping in RNAP- $\lambda P_{R}$ Complexes}

FRET efficiency $E$ (a measure of the fraction of $\mathrm{Cy} 3$ excitation energy that is transferred to Cy5) of a Cy3-Cy5 labeled $\lambda \mathrm{P}_{\mathrm{R}}$ promoter-RNAP complex is calculated from the ratio of the Cy5 emission intensity for excitation at the Cy3 wavelength $(515 \mathrm{~nm})$ to that for excitation at the Cy5 wavelength $\left(610 \mathrm{~nm}\right.$ ), using the Ratio ${ }_{\mathrm{A}}$ method $^{50}$ (see eqs 2 and 3 in Materials and Methods). Table 1 lists occupancy-corrected efficiencies $E$ averaged from all experiments at RNAP:promoter DNA concentration ratios of $<1: 1$ for the CC and OC.

For the CC and OC, the two different arrangements of donor and acceptor dyes at positions -100 and +14 yield similar FRET efficiencies (Table 1), averaging to an $E_{\mathrm{CC}}$ of $0.30 \pm 0.07$ and an $E_{\mathrm{OC}}$ of $0.32 \pm 0.11$. FRET efficiencies of this magnitude indicate that the throughspace distance between -100 and +14 is significantly less than $100 \AA$; model building (see Discussion) indicates that for this to occur both upstream and downstream regions of the promoter DNA must be highly bent and wrapped around RNAP in both the CC and the OC.

Interpretation of these FRET efficiencies using eq 4 shows that dye-dye distances in the CC and OC are approximately 15 and $10 \%$ larger, respectively, than the relevant Förster distance $R_{\mathrm{O}}$ (eq 5) for these dyes. For the Cy3-Cy5 pair in either of the two-dye orientations, if the population-average orientation of one dye with respect to the other in $\mathrm{CC}$ and $\mathrm{OC}$ were relatively random so that $k^{2}$ would equal $2 / 3$, then $R_{\mathrm{O}}$ would be $60 \pm 1 \AA$ for the CC and 56 $\pm 1 \AA$ for the OC. From this $R_{\mathrm{O}}$ and measured $E$ values (Table 1), through-space distances $R$ between -100 and +14 on promoter DNA would be $68 \pm 8 \AA$ for the CC and $62 \pm 8 \AA$ for the OC. These are also similar to the midrange values of $\kappa^{2}$ (between $\kappa_{\min }{ }^{2} \min$ and $\kappa_{\max }{ }^{2}$ ) and $R_{\mathrm{O}}$, from eqs 6 and 7, and so are relevant even if the random orientation limit is inapplicable. Determination of the anisotropies in donor dye and acceptor dye samples allows us to estimate $\kappa_{\min }{ }^{2}$ and $\kappa_{\max }{ }^{2} \cdot{ }^{47,54}$

\section{Fluorescence Anisotropies of Cyanine Dyes on DNA and RNAP- $\lambda P_{R}$ Complexes}

We measured the steady-state fluorescence anisotropy, $r$, of RNAP-promoter complexes and free DNAs to obtain maximal and minimal estimates of $k^{2}$ and to test the relevance of $k^{2}=$ $2 / 3$ for analysis of FRET data for the CC and OC. From the anisotropies, we determine relative mobilities of $\mathrm{Cy} 3$ and $\mathrm{Cy} 5$ dyes in $\mathrm{CC}$ and $\mathrm{OC}$ as compared to those of promoter DNA, primer DNA, and free dyes. Average $r$ values obtained from multiple independent determinations with these different dye-labeled DNAs and RNAP-DNA complexes are listed in Table 2. Also listed are literature values of the anisotropies of the free dyes $[r \approx$ 0.24 for $\mathrm{Cy} 3,46,62,63$ observed to be independent of temperature in the range examined (5$\left.25^{\circ} \mathrm{C}\right) ;{ }^{46} r \approx 0.17$ for $\left.\mathrm{Cy} 5^{62-64}\right]$ and the upper limit for anisotropies $(r=0.4),{ }^{47}$ applicable 
to situations in which the dye is immobile on the time scale of its fluorescence lifetime ${ }^{46,47}$ ( $\sim 2 \mathrm{~ns})$. If these dyes were completely rigidly attached to DNA, and rotated only on the time scale of the DNA or RNAP-DNA complex, their anisotropy is predicted to be 0.4. ${ }^{47}$

Anisotropies between those of the free dyes and the immobilized limit indicate the extent to which the dye can rotate independently of the DNA to which it is attached.

Table 2 shows that, as expected, covalent attachment to the DNA backbone increases the anisotropy of both $\mathrm{Cy} 3$ and Cy5 as compared to that of the free dyes. Anisotropies of both $\mathrm{Cy} 3$ and $\mathrm{Cy} 5$ increase upon progressing from the free dye to the ss dye-labeled primer (26 or 40 bases) to the 114 bp promoter duplex with the dye at an end. Anisotropies of both dyes on both DNAs are somewhat larger at $2{ }^{\circ} \mathrm{C}$ than at $19{ }^{\circ} \mathrm{C}$. Because the anisotropy of free $\mathrm{Cy} 3$ is observed to be independent of temperature, ${ }^{46}$ these small differences may result from increased stacking of these dyes on neighboring nucleobases at $2{ }^{\circ} \mathrm{C}$ versus that at $19{ }^{\circ} \mathrm{C}$. The larger anisotropies of $\mathrm{Cy} 3$ and $\mathrm{Cy} 5$ on ss primers and ds promoter DNA than for the free dyes result from restrictions on rotation of these dyes by incorporation into the backbone of a ss region of DNA and from relatively weak stacking interactions especially with the end of the duplex in promoter DNA. ${ }^{46,53}$

For Cy3 located at +14 , the anisotropy determined for the $\mathrm{OC}\left(19^{\circ} \mathrm{C} ; 0.36 \pm 0.01\right)$ probably exceeds that of the $\mathrm{CC}\left(2{ }^{\circ} \mathrm{C} ; 0.34 \pm 0.02\right)$, and both definitely exceed the anisotropy of $\mathrm{Cy} 3(+14)$ on unbound duplex promoter DNA $\left(0.31 \pm 0.01\right.$ at $19^{\circ} \mathrm{C}$ and $0.32 \pm 0.01$ at $\left.2{ }^{\circ} \mathrm{C}\right)$. These anisotropy increases are consistent with footprinting results that indicate that +14 of promoter DNA is contacted by RNAP in the CC and more strongly contacted in the OC. We conclude that the $\mathrm{Cy} 3(+14)$ is less mobile in the OC and $\mathrm{CC}$ than in free promoter DNA but nonetheless is capable of rotational reorientation independent of the complex, because these anisotropies are significantly less than 0.4 .

For Cy5 located at -100 , the anisotropy determined for the $\mathrm{OC}\left(19^{\circ} \mathrm{C} ; 0.31 \pm 0.03\right)$ is the same or slightly lower than that of the $\mathrm{CC}\left(2{ }^{\circ} \mathrm{C} ; 0.33 \pm 0.03\right)$, and neither is significantly different from the anisotropy of Cy5-100 on unbound duplex promoter DNA $(0.31 \pm 0.03$ at $19{ }^{\circ} \mathrm{C}$ and $0.32 \pm 0.02$ at $2{ }^{\circ} \mathrm{C}$ ). These similar anisotropies at -100 for DNA in the $\mathrm{CC}$ and OC are consistent with footprinting results that indicate that -100 of promoter DNA is not in contact with RNAP in either the CC or the OC. ${ }^{7}$ We conclude that Cy5-100 is as mobile in the $\mathrm{OC}$ and $\mathrm{CC}$ as in free promoter DNA.

\section{Enhanced Fluorescence (PIFE) Is Observed at +14 in the Advanced CC and Stable OC}

Equilibrium studies with a single dye (Cy3 or Cy5) at +14 of $\lambda \mathrm{P}_{\mathrm{R}}$ promoter DNA were performed to study the interactions of this region of the downstream duplex with RNAP in the advanced CC and OC. Cy3 samples were excited at $515 \mathrm{~nm}$ and Cy5 samples at $610 \mathrm{~nm}$. Representative emission spectra for $100 \mathrm{nM} \mathrm{Cy} 5(+14) \lambda \mathrm{P}_{\mathrm{R}}$ in complex with RNAP are shown in Figure 4 . With Cy5 at +14 , the fluorescence emission intensity at $\lambda_{\max }^{\mathrm{em}}$ increases with an increasing RNAP:promoter DNA concentration ratio of up to 1:1 in both the CC $\left[2{ }^{\circ} \mathrm{C}\right.$ (Figure 4A)] and the $\mathrm{OC}\left[19^{\circ} \mathrm{C}\right.$ (Figure 4B)]. The fluorescence increase upon RNAP binding observed here [often called PIFE (protein-induced fluorescence enhancement)] is from the proximity of the dye to the protein $35,37,38,40,41,65$ and is consistent with DNA footprinting evidence ${ }^{7}$ that the +14 region of DNA interacts with the RNAP cleft in both the 
advanced CC and OC. ${ }^{7}$ PIFE effects at $+14(30 \pm 5 \%$ increase in Cy5 fluorescence intensity and $20 \pm 5 \%$ increase in Cy3 fluorescence intensity for complexes compared to free DNA) are similar in the CC and OC (Figure 4 and Figures S5 and S6).

The strong Cy3(+14) PIFE effect masks its expected FRET donor quenching effect in experiments with Cy3(+14)-Cy5(-100) $\lambda \mathrm{P}_{\mathrm{R}}$, as shown in the Cy3 donor emission spectra centered between 555 and $570 \mathrm{~nm}$ in Figure S1. Enhanced fluorescence of the Cy3 donor is observed instead of quenching at all RNAP:promoter DNA concentration ratios, relative to that of a single-dye $\mathrm{Cy} 3$ control in the absence of RNAP. This indicates the dominance of the PIFE effect over the donor quenching FRET effect when Cy3 is at +14 .

\section{Dye-Labeled RNAP- $\lambda \mathrm{P}_{\mathbf{R}}$ Promoter OCs Are Transcriptionally Active and Permanganate Reactive in the Open Region}

Transcription assays were performed to determine whether the OCs formed by RNAP on the cyanine dye-labeled promoter DNAs are capable of specific initiation. Figure 5 demonstrates that all dye-labeled $\lambda \mathrm{P}_{\mathrm{R}}$ promoter fragments initiate transcription and yield significant amounts of the expected-length runoff transcript at $19^{\circ} \mathrm{C}$. The observed differences in transcript length result from differences in the length of duplex DNA downstream of the transcription start site at +1 . For promoter DNAs with a cyanine dye at +14 , the major transcript is $13-14$ bases in length, indicated by the black boxes in Figure 5. For promoters with no dye at +14 (unlabeled $\lambda \mathrm{P}_{\mathrm{R}}$ and $\lambda \mathrm{P}_{\mathrm{R}}$ with a cyanine dye only at -100 ), the downstream duplex extends to +70 , and the longest transcript is observed to be 70 bases long (also indicated by black boxes in Figure 5).

We also compared $\mathrm{MnO}_{4}{ }^{-}$footprints of the dye-labeled and unlabeled (control) RNAPpromoter OC at $19{ }^{\circ} \mathrm{C}$ to test whether these are equally open and have the same pattern of reactive thymine bases in the open region. Nontemplate strands of these promoters were dye-labeled at the upstream end $(-100)$, and template strands of both promoters were ${ }^{32} \mathrm{P}-$ labeled at the downstream end (see Materials and Methods). Transcription experiments (Figure 5) reveal no systematic differences between unlabeled and Cy3(-100)- or Cy5(-100)-labeled promoter DNA. Figure S8A compares template strand $\mathrm{MnO}_{4}{ }^{-}$footprints of RNAP complexes with unlabeled and Cy5(-100)-labeled $\lambda \mathrm{P}_{\mathrm{R}}$ promoter DNA. Thymine bases at the expected positions $(-11,-9,-8$, and +1$)$ were detected in both the Cy5 $(-100)$ and control $\lambda \mathrm{P}_{\mathrm{R}}-\mathrm{RNAP}$ complexes, demonstrating that the dye does not perturb the open region. No such bands are seen in the -RNAP control lanes for either DNA. Intensities of the thymine bands at $-11,-9,-8$, and +1 were quantified and normalized by the intensity of the full-length (unreacted) DNA band to correct for the loading difference between lanes. After correction, no significant difference in permanganate reactivity between the dye-labeled and control $\lambda \mathrm{P}_{\mathrm{R}} \mathrm{OC}$ is observed for any of these four thymines. By contrast, $\mathrm{MnO}_{4}{ }^{-}$experiments performed at $0{ }^{\circ} \mathrm{C}$ on the $\mathrm{CC}$ formed with $\mathrm{Cy} 3(-100) \lambda \mathrm{P}_{\mathrm{R}}$ DNA and dye-free $\lambda \mathrm{P}_{\mathrm{R}}$ DNA reveal no reactivity above background (Figure S8B). 


\section{DISCUSSION}

\section{FRET between Far-Upstream and Downstream Dyes Indicates Extensive Bending and/or Wrapping of Promoter DNA on RNAP in Both Closed and Open Promoter Complexes}

The observation of FRET between dyes at -100 and +14 demonstrates that the throughspace distance between these dyes is $<100 \AA$ in both the CC and the OC. Because the dyedye distance between -100 and +14 in free DNA is $>300 \AA$, both upstream and downstream regions of promoter DNA must be highly bent and wrapped by $E$. coli RNAP in both complexes. For the $\lambda \mathrm{P}_{\mathrm{R}} \mathrm{OC}$, this conclusion is consistent with that derived from AFM compaction measurements, DNaseI and $\mathrm{HO}^{*}$ footprinting, and other assays at both $\lambda \mathrm{P}_{\mathrm{R}}$ and other promoters, summarized below. For the advanced $\lambda \mathrm{P}_{\mathrm{R}} \mathrm{CC}$, this conclusion is consistent with $\mathrm{HO}^{\bullet}$ footprinting data, the model proposed by Davis et al., ${ }^{7}$ and AFM compaction measurements at the TyrT promoter. $^{23}$

On the basis of the kinetic and footprinting results summarized in the introductory section, we $\mathrm{e}^{1,7,12}$ proposed that upstream wrapping occurs as the RNAP molecular machine converts the earliest $\mathrm{CC}$ to an advanced $\mathrm{CC}$, and that this upstream wrapping causes conformational changes in RNAP that make it possible to bend the downstream duplex at -11 into the active site cleft, nucleating promoter DNA melting. The significance of wrapping for the properties of OC, including its stability and ability to initiate efficiently upon addition of NTPs, is not yet known.

\section{The +14 PIFE Effect at $2{ }^{\circ} \mathrm{C}$ Indicates the CC Is Advanced, with Downstream DNA Bent into the RNAP Cleft}

The enhanced fluorescence of DNA-attached cyanine dyes was originally observed upon binding of SSB, BamHI, RecA, and RadH1 to neighboring sites. ${ }^{35,36,39}$ Myong et al. designated this effect PIFE and showed that it is detectable at a dye-protein distance of $34 \AA$ and increases with a decreasing dye-protein distance. ${ }^{36}$ PIFE between RNAP and a cyanine dye at +2 on promoter DNA has recently been used to study initiation and backtracking events upon addition of NTP to OC, ${ }^{37,38}$ OC dissociation kinetics, ${ }^{41}$ and effects of the CarD regulatory protein on OC formation. ${ }^{40}$ PIFE (and also FRET) has also been used to investigate interactions of histone $\mathrm{H} 1$ with transcriptional activator Gal4. ${ }^{65}$ Here the observation of +14 PIFE in the $2{ }^{\circ} \mathrm{C} \mathrm{CC}$ corroborates information from footprinting ${ }^{14}$ and FRET that this $\mathrm{CC}$ is advanced, with the downstream duplex bent into the active site cleft as proposed previously. ${ }^{1,12}$ These +14 PIFE effects in CC may reflect interactions with DME of RNAP, which include the lineage-specific insert $\beta$ i 4 (also called Sequence Insertion 1 or SI1), the $\beta$ clamp, and the $\beta$ jaw (see Figure $6 \mathrm{~A}, \mathrm{~B}$ ). ${ }^{4,5}$ In the early $\mathrm{CC}$ at other promoters $\left(\mathrm{RP}_{\mathrm{c}}\right.$ ), where the promoter DNA is linear (not yet bent), the downstream boundary of the $\mathrm{HO}^{\bullet}$ or DNaseI footprint is at the discriminator region $(-7$ to -2$){ }^{9}{ }^{9} 10$ Hence, in $\mathrm{RP}_{\mathrm{c}}$, the distance between RNAP and +14 of promoter DNA greatly exceeds $34 \AA$ and no PIFE would be expected. The +14 PIFE effect observed for the stable OC is expected on the basis of footprinting and RNAP deletion variant data that indicate that this position is contacted by the $\beta$ jaw and possibly other DMEs., 4 


\section{Through-Space Distances between Far-Upstream and Downstream Regions of Promoter DNA Bent and Wrapped on RNAP in Closed and Open Complexes}

Here we interpret FRET efficiencies and anisotropies for the $\mathrm{CC}$ and $\mathrm{OC}$ to estimate upper and lower bounds on interdye distances in the bent/wrapped CC and OC and compare them with predictions from AFM compaction data and, in a subsequent section, from structural models built with input from DNA footprinting data.

OC and CC anisotropy data (Table 2) demonstrate that $\mathrm{Cy} 3$ at +14 is relatively immobile while Cy5 at -100 is more mobile. For the situation in which one dye is immobile and the other is free to rotate independently, a 4-fold range of values of $k^{2}$ is possible, centered at $k^{2}$ $=2 / 3\left(\kappa_{\min }^{2}=1 / 3\right.$, and $\left.\kappa_{\max }^{2}=4 / 3\right)$. This 4 -fold range of possible values of $\kappa^{2}$ translates into only an additional $\pm 26 \%$ uncertainty in distance $R$ between positions -100 and +14 because $R$ varies with $\left(k^{2}\right)^{1 / 6}$. Combined with the experimental uncertainty in FRET efficiency, this leads to an uncertainty in $R$ of $\pm 36 \%$ in dye-dye distances for both the CC and the OC. However, while the anisotropy of Cy5(-100) is approximately the same within uncertainty in the CC and OC as in free DNA, it exceeds that of the free DNA and the ss primer DNA (Table 2), presumably because cyanine dyes at the end of a duplex, like Cy5(-100), are partially stacked on the duplex and not completely free to reorient. ${ }^{46,53}$ Application of eqs 6 and 7 to obtain minimal and maximal values of $k^{2}, R_{\mathrm{o}}$, and $R$ from the anisotropy results increases the combined uncertainty in the determination of $R$ for the CC and OC from the measured $E$ and $r$ values to $\pm 60 \%$, in a range centered on the $R$ values for these complexes calculated for $k^{2}=2 / 3$.

\section{Structural Models for the CC and OC Consistent with FRET and Footprinting Data}

To interpret the strong FRET efficiencies of closed and open RNAP-promoter complexes and to obtain structural models for DNA wrapping tracks on RNAP, we model upstream (and, for CC, downstream) DNA onto recent crystal structures of $E$. coli RNAP holoenzyme $(\text { for } \mathrm{CC})^{58}$ and a ternary initiation complex with an open region from -11 to +4 and a downstream duplex extending to position +13 (for OC), ${ }^{61}$ using $\mathrm{HO}^{\bullet}$ footprinting data for promoter DNA in the advanced $\mathrm{CC}$ and the stable $\mathrm{OC}$ as a guide.

Advanced Closed Complex-Our modeling of DNA bending and wrapping in the advanced CC updates and extends the previously published model, which was based on the structure of T. thermophilus RNAP. ${ }^{7}$ In that CC model, the promoter DNA is wrapped in an approximate U-turn around RNAP, with an overall bend angle of $>200^{\circ}$, resulting in upstream contacts between RNAP and promoter DNA to position $-81 /-82$ as evident in the $\mathrm{HO}^{\circ}$ footprint. The distance $R$ between upstream (-100) and downstream (+14) positions in this model is $85 \AA$, near the upper end of the range consistent with the FRET efficiency reported here (Table 1). Replacement of $T$. thermophilus RNAP by E. coli RNAP has little effect on upstream contacts or on the distance $R$ between -100 and +14 . Slight bending of the upstream DNA at -65 in this CC model creates a series of wrapped complexes with smaller distances $R$ but similar upstream boundaries near -82 (see Figure S9). For example, an $\sim 8^{\circ}$ bend at -65 reduces $R$ to $\sim 50 \AA$, the minimal distance that is obtained by this approach without introducing steric clash. An $\sim 5^{\circ}$ bend at -65 yields the $\mathrm{CC}$ structure of Figure 6A with an $R$ of $68 \AA$, the midrange distance deduced from the FRET efficiency and 
isotropy of the CC. Models of the advanced CC built with an $R$ of $<50 \AA$ Antroduce steric clash and are also incompatible with the known footprinting data. ${ }^{7}$ Any large conformational changes in RNAP in the conversion from the free protein $^{58}$ to the advanced CC modeled here could affect this conclusion.

Stable Open Complex-Though the FRET efficiencies for energy transfer between positions -100 and +14 are similar for the advanced CC and $\mathrm{OC} \lambda \mathrm{P}_{\mathrm{R}}-\mathrm{RNAP}$ complexes, the structures of these complexes must differ significantly in both upstream and downstream regions. Upstream DNA in both the advanced CC and the stable OC is predicted to be strongly bent between -35 and $-55,{ }^{7,13}$ indicating the trajectory of the upstream wrap begins similarly in both complexes, but they exhibit very different upstream boundaries of $\mathrm{HO}^{\circ}$ protection $\left(-81 /-82\right.$ in the advanced CC and $-60 /-65$ in the stable OC) ${ }^{7}$ Hence, the trajectory of the far-upstream DNA (between $-60 /-65$ and -81/-82) and/or the positions of elements of RNAP, including $\beta$ residues 808-912 (previously designated the UP clamp), ${ }^{1,4}$ that appear to make contact with this far-upstream DNA must shift in the conversion of the advanced CC to the stable OC.

Likewise, the trajectories of the downstream DNA in the advanced CC and stable OC appear to be different. Both complexes have an $\sim 90^{\circ}$ bend at the upstream end of the -10 region and the same downstream boundary of $\mathrm{HO}^{\circ}$ protection $(+20) .{ }^{7}$ However, while the DNA downstream of the bend at -11 is thought to be linear in the advanced CC, additional strong bending in the open region is observed in the recent structure of an initiation complex, ${ }^{61}$ altering the downstream duplex trajectory. The +14 region of downstream DNA is in the proximity of, and possibly interacting with, $\beta$ SI1 (residues 227-308) in the advanced CC (Figure 6A) but is farther from it in the OC, indicating rearrangement of either this region of RNAP or the downstream DNA in the conversion of the CC to the OC. The $\beta$ jaw (residues 1150-1208) is also closer to DNA downstream of position +10 in the OC (Figure 6B), supporting earlier evidence of stabilizing interactions between the $\beta$ jaw and this region of downstream DNA in the OC. ${ }^{4,5}$

Starting from the structure of the initiation complex, ${ }^{61}$ we modeled in the upstream DNA as described in Materials and Methods to create upstream-wrapped structures with distances $R$ between -100 and +14 in the range of $40-80 \AA$ as specified by the FRET efficiency, in which the upstream DNA contacts RNAP only to the upstream end of the UP element at $-60 /-65$ to match the upstream $\mathrm{HO}^{\bullet}$ footprint boundary, and with the extreme wrapping deduced from DNA compaction by AFM. ${ }^{20}$ If upstream DNA (from -37 to -99) from the CC model (Figure 6A) is modeled into the structure of the initiation complex without any additional bending, we obtain an OC model with an $R$ of $>100 \AA$ and in which the tethers of the $a$ CTD must be somewhat extended to make contacts with the UP element DNA.

This OC model does not have sufficient upstream bending and wrapping to explain the OC FRET efficiency. To reduce $R$, bends in upstream duplex DNA at positions of DNaseI or $\mathrm{HO}^{\bullet}$ enhancements ${ }^{7,14}$ were increased by small amounts $\left(\sim 3^{\circ}\right)$ at -38 and -44 and substantially $\left(\sim 25^{\circ}\right)$ at -54 , relative to the path of the DNA in the original CC model. This OC structure $(R=62 \AA)$ is shown in Figure 6B. More extensive bending at these or other positions would force contacts between upstream DNA and RNAP beyond -60/-65, not 
observed in the $\mathrm{OC} \mathrm{HO}^{\bullet}$ footprint. ${ }^{7}$ Insertion of an $\sim 25^{\circ}$ bend at -54 changes the trajectory of upstream DNA from that of the CC model (in which it is near the $\alpha$-NTD and the $\beta$ groove), shifting the upstream DNA toward the $\omega$ subunit. Upstream DNA beyond -65 passes near the $\beta$ subunit without a direct interaction, consistent with the end point of the $\mathrm{HO}^{\bullet}$ footprint at -65 on the nucleotide strand. ${ }^{7}$ The upstream (-100)- downstream $(+14)$ distance $R$ in this structure is $62 \AA$, which is also the midrange distance from FRET/ anisotropy data. Smaller values of $R$ are not possible in this model because of steric interactions, unless there are large conformational differences in the region of RNAP contacting the upstream DNA between the stable OC and the initiation complex. While phasing and positioning of upstream DNA with respect to RNAP in this model are approximate and traced by eye, we think it provides a good estimate of the most probable distance in the $\mathrm{OC}$ between -100 and +14 .

\section{Possible Roles of Promoter DNA Wrapping and Unwrapping in OC Formation and Transcription Initiation}

Truncations of far-upstream promoter DNA (between -65 and -100$)^{6}$ and within the UP element $(-38 \text { to }-65)^{6,8}$ both dramatically reduce the rate of isomerization of closed to open complexes at $\lambda \mathrm{P}_{\mathrm{R}}$ and lacUV5 promoters. While the real-time footprint of the ensemble of advanced closed complexes at $\lambda \mathrm{P}_{\mathrm{R}}$ extends from -82 to +20 , truncation at -47 results in a less advanced closed complex, with a downstream boundary in real-time footprinting of only $+2 /+7$ that indicates that the downstream duplex is only partially bent into the active site cleft. ${ }^{7}$ From this information, we proposed that upstream bending and wrapping, set in motion by initial binding to the -35 region and the UP element to form a linear complex $\left(\mathrm{RP}_{\mathrm{c}}\right)$, are necessary to bend the downstream duplex fully into the cleft in the advanced CC prior to opening. Presumably, this is because upstream bending and wrapping play key roles in opening the cleft and moving obstacles like sigma 1.1 and DME of core RNAP to allow bending of the downstream duplex at -11 and its entry into the active site cleft before opening. $4,5,12,66$

The significance of wrapping for the properties of OC is unknown. AFM studies with fulllength $\lambda \mathrm{P}_{\mathrm{R}}$ indicate similar degrees of wrapping in $\mathrm{OC}$ and in an initiation complex paused at $+3 .{ }^{22}$ Because elongation complexes (after escape from the promoter) exhibit a short (40 bp) footprint ${ }^{19}$ and are therefore unwrapped, unwrapping of the upstream DNA may therefore be a significant element of the transition from initiation to elongation that occurs after formation of a moderately long transcript ( 10 bp RNA-DNA hybrid), which necessitates and may be driven by scrunching of promoter DNA in the cleft. ${ }^{67,68}$ Release of upstream wrapping presumably coincides with release of specific RNAP-promoter DNA interactions.

\section{Comparison of Promoter DNA Wrapping in the CC Formed by Prokaryotic and Eukaryotic RNAP}

Wrapping of upstream DNA and bending of downstream DNA appear to be general features of preinitiation complexes for eukaryotic as well as bacterial RNAP. After binding the TATA box, human and yeast TATA binding proteins (TBP) and transcription factor TFIIB together bend this sequence of duplex DNA by $80-100^{\circ 69}$ in a manner reminiscent of the bending of 
the region upstream of the -35 element by $E$. coli RNAP to form an advanced CC. ${ }^{1,14}$ Assisted by the essential factor TFIIF (required for binding of RNA pol II to promoter DNA) and TFIIE, another $\sim 90^{\circ}$ bend is formed near the transcription initiation site ${ }^{30,70}(+1)$, which may be analogous to the downstream bending of DNA at -11 into the active site cleft in $E$. coli RNAP in an advanced $\mathrm{CC}^{1,12,66}$ that also has been implicated in nucleation of DNA opening. ${ }^{71}$ Extensive protein-DNA cross-linking is observed over a 90 bp region of promoter DNA $(-56 \text { to }+34)^{31}$ in an advanced CC formed with TBP, TFIIB, RNA pol II, TFIIF, and TFIIE, indicating extensive DNA wrapping analogous to the $\sim 100 \mathrm{bp}$ of DNA wrapped by $E$. coli RNAP in the advanced CC (from $-80 /-81$ to +20 ). ${ }^{7}$ We hypothesize that eukaryotic initiation factors such as TFIIE and TFIIF, and $E$. coli RNAP $\beta$ lobe (including SI1) and the $\beta$ UP clamp, ${ }^{4}$ may function similarly in wrapping promoter DNA in the advanced CC. Kinetic studies are underway in our laboratory to determine the progression of upstream DNA wrapping and downstream DNA bending as the initial closed complex $\left(\mathrm{RP}_{\mathrm{c}}\right)$ advances to bend the downstream duplex into the active site cleft and open it.

\section{Supplementary Material}

Refer to Web version on PubMed Central for supplementary material.

\section{Acknowledgments}

Fluorescence data were obtained at the University of Wisconsin—Madison Biophysics Instrumentation Facility, which was established with support from the University of Wisconsin-Madison and Grants BIR-9512577 (National Science Foundation) and S10RR13790 (National Institutes of Health).

Funding

This research was supported by National Institutes of Health Grants GM103061 (M.T.R.) and GM 67153 (I.A.).

\section{ABBREVIATIONS}

$\begin{array}{ll}\text { RNAP } & \text { RNA polymerase } \\ \text { CC } & \text { closed complex } \\ \text { OC } & \text { open complex } \\ \text { DME } & \text { downstream mobile element } \\ \text { PIFE } & \text { protein-induced fluorescence enhancement } \\ \text { AFM } & \text { atomic force microscopy } \\ \text { CTD } & \text { C-terminal domain } \\ \text { NTD } & \text { N-terminal domain } \\ \text { SB } & \text { storage buffer } \\ \text { FB } & \text { buffer for fluorescence experiments } \\ \text { AB } & \text { annealing buffer } \\ \text { TB } & \text { transcription buffer }\end{array}$


QB quench buffer

SI sequence insertion

t template

nt nontemplate

wt wild-type

HO hydroxyl radical

\section{References}

1. Saecker RM, Record MT, Dehaseth PL. Mechanism of bacterial transcription initiation: RNA polymerase - promoter binding, isomerization to initiation-competent open complexes, and initiation of RNA synthesis. J Mol Biol. 2011; 412:754-771.

2. Ruff EF, Record MT, Artsimovitch I. Initial events in bacterial transcription initiation. Biomolecules. 2015; 5:1035-1062.

3. Mekler V, Minakhin L, Borukhov S, Mustaev A, Severinov K. Coupling of downstream RNA polymerase-promoter interactions with formation of catalytically competent transcription initiation complex. J Mol Biol. 2014; 426:3973-3984.

4. Drennan A, Kraemer M, Capp M, Gries T, Ruff E, Sheppard C, Wigneshweraraj S, Artsimovitch I, Record MT. Key roles of the downstream mobile jaw of Escherichia coli RNA polymerase in transcription initiation. Biochemistry. 2012; 51:9447-9459. [PubMed: 23116321]

5. Ruff EF, Drennan AC, Capp MW, Poulos MA, Artsimovitch I, Record MT. E. coli RNA Polymerase Determinants of Open Complex Lifetime and Structure. J Mol Biol. 2015; 427:2435-2450. [PubMed: 26055538]

6. Ross W, Gourse RL. Sequence-independent upstream DNA-alphaCTD interactions strongly stimulate Escherichia coli RNA polymerase-lacUV5 promoter association. Proc Natl Acad Sci U S A. 2005; 102:291-296. [PubMed: 15626760]

7. Davis CA, Bingman CA, Landick R, Record MT, Saecker RM. Real-time footprinting of DNA in the first kinetically significant intermediate in open complex formation by Escherichia coli RNA polymerase. Proc Natl Acad Sci U S A. 2007; 104:7833-7838. [PubMed: 17470797]

8. Davis CA, Capp MW, Record MT, Saecker RM. The effects of upstream DNA on open complex formation by Escherichia coli RNA polymerase. Proc Natl Acad Sci U S A. 2005; 102:285-290. [PubMed: 15626761]

9. Mecsas J, Cowing DW, Gross CA. Development of RNA polymerase-promoter contacts during open complex formation. J Mol Biol. 1991; 220:585-597. [PubMed: 1651395]

10. Cowing DW, Mecsas J, Record MT, Gross CA. Intermediates in the formation of the open complex by RNA polymerase holoenzyme containing the sigma factor sigma 32 at the groE promoter. $\mathrm{J}$ Mol Biol. 1989; 210:521-530. [PubMed: 2693737]

11. Kovacic RT. The 0 degree $C$ closed complexes between Escherichia coli RNA polymerase and two promoters, T7-A3 and lacUV5. J Biol Chem. 1987; 262:13654-13661. [PubMed: 3308880]

12. Saecker RM, Tsodikov OV, McQuade KL, Schlax PEJ, Capp MW, Record MT. Kinetic studies and structural models of the association of E. coli sigma(70) RNA polymerase with the lambdaP(R) promoter: large scale conformational changes in forming the kinetically significant intermediates. J Mol Biol. 2002; 319:649-671. [PubMed: 12054861]

13. Craig ML, Suh WC, Record MT. HO. and DNase I probing of E sigma 70 RNA polymeraselambda PR promoter open complexes: $\mathrm{Mg} 2+$ binding and its structural consequences at the transcription start site. Biochemistry. 1995; 34:15624-15632. [PubMed: 7495790]

14. Craig ML, Tsodikov OV, McQuade KL, Schlax PEJ, Capp MW, Saecker RM, Record MT. DNA footprints of the two kinetically significant intermediates in formation of an RNA polymerasepromoter open complex: evidence that interactions with start site and downstream DNA induce 
sequential conformational changes in polymerase and DNA. J Mol Biol. 1998; 283:741-756. [PubMed: 9790837]

15. Gries TJ, Kontur WS, Capp MW, Saecker RM, Record MT. One-step DNA melting in the RNA polymerase cleft opens the initiation bubble to form an unstable open complex. Proc Natl Acad Sci U S A. 2010; 107:10418-10423. [PubMed: 20483995]

16. Kontur WS, Saecker RM, Capp MW, Record MT. Late steps in the formation of E. coli RNA polymerase-lambda P R promoter open complexes: characterization of conformational changes by rapid [perturbant] upshift experiments. J Mol Biol. 2008; 376:1034-1047. [PubMed: 18191943]

17. Roe JH, Burgess RR, Record MT. Temperature dependence of the rate constants of the Escherichia coli RNA polymerase- $\lambda$ PR promoter interaction. J Mol Biol. 1985; 184:441-453. [PubMed: 3900414]

18. Roe JH, Burgess RR, Record MT. Kinetics and mechanism of the interaction of Escherichia coli RNA polymerase with the lambda PR promoter. J Mol Biol. 1984; 176:495-522. [PubMed: 6235375]

19. Carpousis AJ, Gralla JD. Interaction of RNA polymerase with lacUV5 promoter DNA during mRNA initiation and elongation. J Mol Biol. 1985; 183:165-177. [PubMed: 2409292]

20. Rivetti C, Guthold M, Bustamante C. Wrapping of DNA around the E. coli RNA polymerase open promoter complex. EMBO J. 1999; 18:4464-4475. [PubMed: 10449412]

21. Doniselli N, Rodriguez-Aliaga P, Amidani D, Bardales JA, Bustamante C, Guerra DG, Rivetti C. New insights into the regulatory mechanisms of ppGpp and DksA on Escherichia coli RNA polymerase-promoter complex. Nucleic Acids Res. 2015; 43:5249-5262. [PubMed: 25916853]

22. Rivetti C, Codeluppi S, Dieci G, Bustamante C. Visualizing RNA Extrusion and DNA Wrapping in Transcription Elongation Complexes of Bacterial and Eukaryotic RNA Polymerases. J Mol Biol. 2003; 326:1413-1426. [PubMed: 12595254]

23. Maurer S, Fritz J, Muskhelishvili G, Travers A. RNA polymerase and an activator form discrete subcomplexes in a transcription initiation complex. EMBO J. 2006; 25:3784-3790. [PubMed: 16888625]

24. Schultz SC, Shields GC, Steitz TA. Crystal structure of a CAP-DNA complex: the DNA is bent by 90 degrees. Science. 1991; 253:1001-1007. [PubMed: 1653449]

25. Muskhelishvili G, Buckle M, Heumann H, Kahmann R, Travers AA. FIS activates sequential steps during transcription initiation at a stable RNA promoter. EMBO J. 1997; 16:3655-3665. [PubMed: 9218806]

26. Outten CE, Outten FW, O'Halloran TV. DNA distortion mechanism for transcriptional activation by ZntR, a Zn(II)-responsive MerR homologue in Escherichia coli. J Biol Chem. 1999; 274:37517-37524. [PubMed: 10608803]

27. Philips SJ, Canalizo-Hernandez M, Yildirim I, Schatz GC, Mondragon A, O'Halloran TV. Allosteric transcriptional regulation via changes in the overall topology of the core promoter. Science. 2015; 349:877-881. [PubMed: 26293965]

28. Frantz B, O'Halloran TV. DNA distortion accompanies transcriptional activation by the metalresponsive gene-regulatory protein MerR. Biochemistry. 1990; 29:4747-4751. [PubMed: 2364056]

29. Forget D, Robert F, Grondin G, Burton ZF, Greenblatt J, Coulombe B. RAP74 induces promoter contacts by RNA polymerase II upstream and downstream of a DNA bend centered on the TATA box. Proc Natl Acad Sci U S A. 1997; 94:7150-7155. [PubMed: 9207059]

30. Kim TK, Lagrange T, Wang YH, Griffith JD, Reinberg D, Ebright RH. Trajectory of DNA in the RNA polymerase II transcription preinitiation complex. Proc Natl Acad Sci U S A. 1997; 94:12268-12273. [PubMed: 9356438]

31. Robert F, Douziech M, Forget D, Egly JM, Greenblatt J, Burton ZF, Coulombe B. Wrapping of promoter DNA around the RNA polymerase II initiation complex induced by TFIIF. Mol Cell. 1998; 2:341-351. [PubMed: 9774972]

32. Schickor P, Metzger W, Werel W, Lederer H, Heumann H. Topography of intermediates in transcription initiation of E. coli. EMBO J. 1990; 9:2215-2220. [PubMed: 2192861]

33. Amouyal M, Buc H. Topological unwinding of strong and weak promoters by RNA polymerase. J Mol Biol. 1987; 195:795-808. [PubMed: 3309341] 
34. Zinkel SS, Crothers DM. Catabolite activator protein-induced DNA bending in transcription initiation. J Mol Biol. 1991; 219:201-215. [PubMed: 1645410]

35. Kozlov AG, Lohman TM. Stopped-flow studies of the kinetics of single-stranded DNA binding and wrapping around the Escherichia coli SSB tetramer. Biochemistry. 2002; 41:6032-6044. [PubMed: 11993998]

36. Hwang H, Myong S. Protein induced fluorescence enhancement (PIFE) for probing proteinnucleic acid interactions. Chem Soc Rev. 2014; 43:1221-1229. [PubMed: 24056732]

37. Ko J, Heyduk T. Kinetics of promoter escape by bacterial RNA polymerase: effects of promoter contacts and transcription bubble collapse. Biochem J. 2014; 463:135-144. [PubMed: 24995916]

38. Lass-Napiorkowska A, Heyduk T. Real-Time Observation of Backtracking by Bacterial RNA Polymerase. Biochemistry. 2016; 55:647-658.

39. Hwang H, Kim H, Myong S. Protein induced fluorescence enhancement as a single molecule assay with short distance sensitivity. Proc Natl Acad Sci U S A. 2011; 108:7414-7418. [PubMed: 21502529]

40. Rammohan J, Ruiz Manzano A, Garner AL, Stallings CL, Galburt EA. CarD stabilizes mycobacterial open complexes via a two-tiered kinetic mechanism. Nucleic Acids Res. 2015; 43:3272-3285. [PubMed: 25697505]

41. Bae B, Feklistov A, Lass-Napiorkowska A, Landick R, Darst SA. Structure of a bacterial RNA polymerase holoenzyme open promoter complex. eLife. 2015; 410.7554/eLife.08504

42. McClelland M, Hanish J, Nelson M, Patel Y. KGB: a single buffer for all restriction endonucleases. Nucleic Acids Res. 1988; 16:364. [PubMed: 2893340]

43. Leirmo S, Harrison C, Cayley DS, Burgess RR, Record MT. Replacement of potassium chloride by potassium glutamate dramatically enhances protein-DNA interactions in vitro. Biochemistry. 1987; 26:2095-2101. [PubMed: 2887198]

44. Svetlov V, Artsimovitch I. Purification of bacterial RNA polymerase: tools and protocols. Methods Mol Biol. 2015; 1276:13-29. [PubMed: 25665556]

45. Borukhov S, Goldfarb A. Recombinant Escherichia coli RNA polymerase: purification of individually overexpressed subunits and in vitro assembly. Protein Expression Purif. 1993; 4:503511.

46. Sanborn ME, Connolly BK, Gurunathan K, Levitus M. Fluorescence properties and photophysics of the sulfoindocyanine Cy3 linked covalently to DNA. J Phys Chem B. 2007; 111:11064-11074. [PubMed: 17718469]

47. Lakowicz, JR. Principles of fluorescence spectroscopy. 3rd. Springer; Boston: 2006.

48. Chen RF, Bowman RL. Fluorescence Polarization: Measurement with Ultraviolet-Polarizing Filters in a Spectrophotofluorometer. Science. 1965; 147:729-732. [PubMed: 14242017]

49. Bloomfield VA. Survey of Biomolecular Hydrodynamics. OnLine Biophys Textb. 2000:1-16.

50. Clegg RM. Fluorescence resonance energy transfer and nucleic acids. Methods Enzymol. 1992; 211:353-388. [PubMed: 1406315]

51. Szilvay GR, Blenner MA, Shur O, Cropek DM, Banta S. A FRET-based method for probing the conformational behavior of an intrinsically disordered repeat domain from Bordetella pertussis adenylate cyclase. Biochemistry. 2009; 48:11273-11282. [PubMed: 19860484]

52. Malicka J, Gryczynski I, Kusba J, Lakowicz JR. Effects of metallic silver island films on resonance energy transfer between N,N'-(dipropyl)-tetramethyl- indocarbocyanine (Cy3)- and N,N'(dipropyl)-tetramethyl- indodicarbocyanine (Cy5)-labeled DNA. Biopolymers. 2003; 70:595-603. [PubMed: 14648769]

53. Iqbal A, Arslan S, Okumus B, Wilson TJ, Giraud G, Norman DG, Ha T, Lilley DMJ. Orientation dependence in fluorescent energy transfer between $\mathrm{Cy} 3$ and Cy5 terminally attached to doublestranded nucleic acids. Proc Natl Acad Sci U S A. 2008; 105:11176-11181. [PubMed: 18676615]

54. Ivanov V, Li M, Mizuuchi K. Impact of emission anisotropy on fluorescence spectroscopy and FRET distance measurements. Biophys J. 2009; 97:922-929. [PubMed: 19651051]

55. Sasse-Dwight S, Gralla JD. KMnO4 as a probe for lac promoter DNA melting and mechanism in vivo. J Biol Chem. 1989; 264:8074-8081. [PubMed: 2722774] 
56. Schneider CA, Rasband WS, Eliceiri KW. NIH Image to ImageJ: 25 years of image analysis. Nat Methods. 2012; 9:671-675. [PubMed: 22930834]

57. Emsley P, Cowtan K. Coot: model-building tools for molecular graphics. Acta Crystallogr, Sect D: Biol Crystallogr. 2004; 60:2126-2132. [PubMed: 15572765]

58. Bae B, Davis E, Brown D, Campbell EA, Wigneshweraraj S, Darst SA. Phage T7 Gp2 inhibition of Escherichia coli RNA polymerase involves misappropriation of sigma70 domain 1.1. Proc Natl Acad Sci U S A. 2013; 110:19772-19777. [PubMed: 24218560]

59. Benoff B, Yang H, Lawson CL, Parkinson G, Liu J, Blatter E, Ebright YW, Berman HM, Ebright RH. Structural basis of transcription activation: the CAP-alpha CTD-DNA complex. Science. 2002; 297:1562-1566. [PubMed: 12202833]

60. Ross W, Schneider DA, Paul BJ, Mertens A, Gourse RL. An intersubunit contact stimulating transcription initiation by $E$. coli RNA polymerase: interaction of the alpha C-terminal domain and sigma region 4. Genes Dev. 2003; 17:1293-1307. [PubMed: 12756230]

61. Zuo Y, Steitz TA. Crystal Structures of the E. coli Transcription Initiation Complexes with a Complete Bubble. Mol Cell. 2015; 58:534-540. [PubMed: 25866247]

62. Kobitski AY, Nierth A, Helm M, Jäschke A, Nienhaus GU. Mg2+-dependent folding of a DielsAlderase ribozyme probed by single-molecule FRET analysis. Nucleic Acids Res. 2007; 35:20472059. [PubMed: 17344321]

63. Yasuda R, Masaike T, Adachi K, Noji H, Itoh H, Kinosita K. The ATP-waiting conformation of rotating F1-ATPase revealed by single-pair fluorescence resonance energy transfer. Proc Natl Acad Sci U S A. 2003; 100:9314-9318. [PubMed: 12876203]

64. Lee JY, Wei S, Lee T-H. Effects of histone acetylation by Piccolo NuA4 on the structure of a nucleosome and the interactions between two nucleosomes. J Biol Chem. 2011; 286:11099-11109. [PubMed: 21282115]

65. Bernier M, Luo Y, Nwokelo KC, Goodwin M, Dreher SJ, Zhang P, Parthun MR, FondufeMittendorf Y, Ottesen JJ, Poirier MG. Linker histone H1 and H3K56 acetylation are antagonistic regulators of nucleosome dynamics. Nat Commun. 2015; 6:10152. [PubMed: 26648124]

66. Vassylyev DG, Sekine S, Laptenko O, Lee J, Vassylyeva MN, Borukhov S, Yokoyama S. Crystal structure of a bacterial RNA polymerase holoenzyme at 2.6 A resolution. Nature. 2002 ; 417:712719. [PubMed: 12000971]

67. Revyakin A, Liu C, Ebright RH, Strick TR. Abortive initiation and productive initiation by RNA polymerase involve DNA scrunching. Science. 2006; 314:1139-1143. [PubMed: 17110577]

68. Kapanidis AN, Margeat E, Ho SO, Kortkhonjia E, Weiss S, Ebright RH. Initial transcription by RNA polymerase proceeds through a DNA-scrunching mechanism. Science. 2006; 314:11441147. [PubMed: 17110578]

69. Sainsbury S, Bernecky C, Cramer P. Structural basis of transcription initiation by RNA polymerase II. Nat Rev Mol Cell Biol. 2015; 16:129-143. [PubMed: 25693126]

70. He Y, Fang J, Taatjes DJ, Nogales E. Structural visualization of key steps in human transcription initiation. Nature. 2013; 495:481-486. [PubMed: 23446344]

71. Feklistov A, Darst SA. Structural basis for promoter - 10 element recognition by the bacterial RNA polymerase $\sigma$ subunit. Cell. 2011; 147:1257-1269. [PubMed: 22136875] 
A.

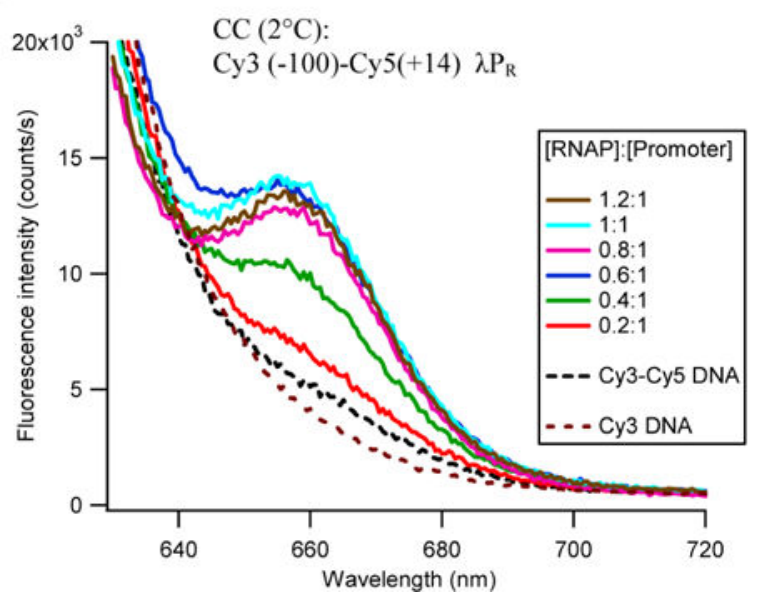

B.

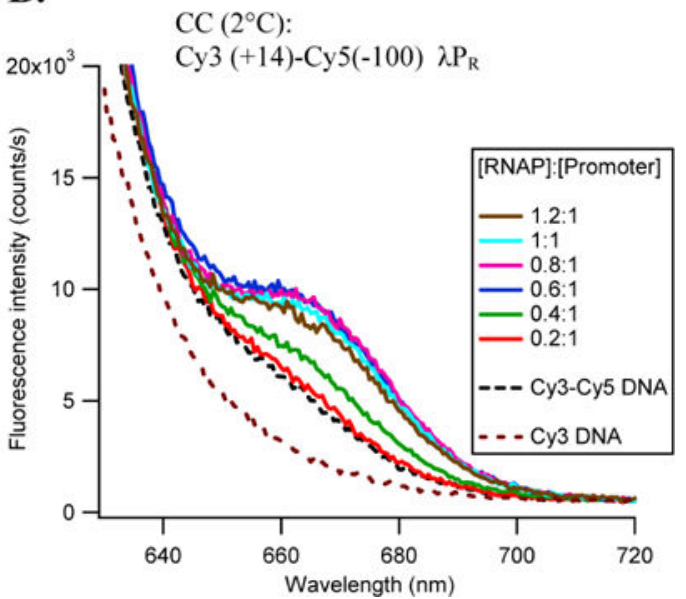

Figure 1.

Donor (Cy3) to acceptor (Cy5) fluorescence energy transfer (FRET) demonstrating wrapping in CC. Cy5 fluorescence emission spectra $(620-720 \mathrm{~nm}$; counts per second) obtained by excitation of $\mathrm{Cy} 3$ at $515 \mathrm{~nm}$ as a function of RNAP:promoter DNA concentration ratio $\left(0-1.2: 1 ; 100 \mathrm{nM}\right.$ DNA) for advanced closed $\left(\mathrm{CC} ; 2{ }^{\circ} \mathrm{C}\right) \mathrm{RNAP}-\lambda \mathrm{P}_{\mathrm{R}}$ promoter DNA complexes: (A) Cy3(-100)-Cy5(+14) $\lambda \mathrm{P}_{\mathrm{R}}$ and (B) Cy3(+14)-Cy5(-100) $\lambda \mathrm{P}_{\mathrm{R}}$. DNA spectra (-RNAP) were obtained with $100 \mathrm{nM}$ Cy3-labeled DNA and Cy3-Cy5 labeled DNA. 
A.

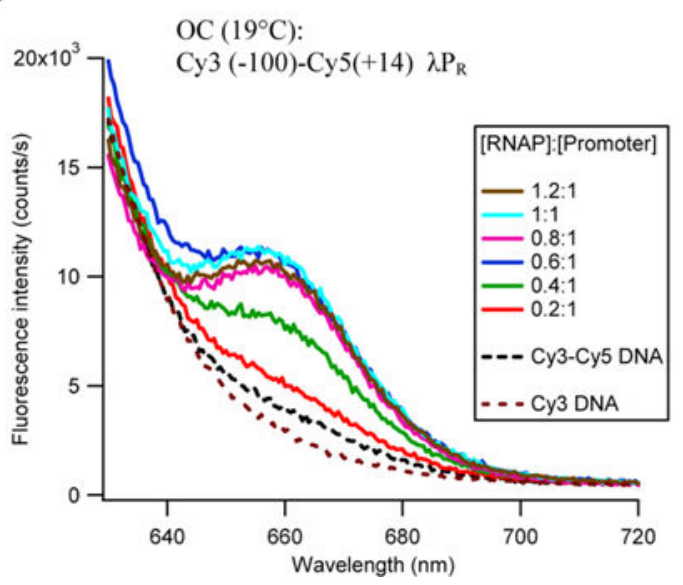

B.

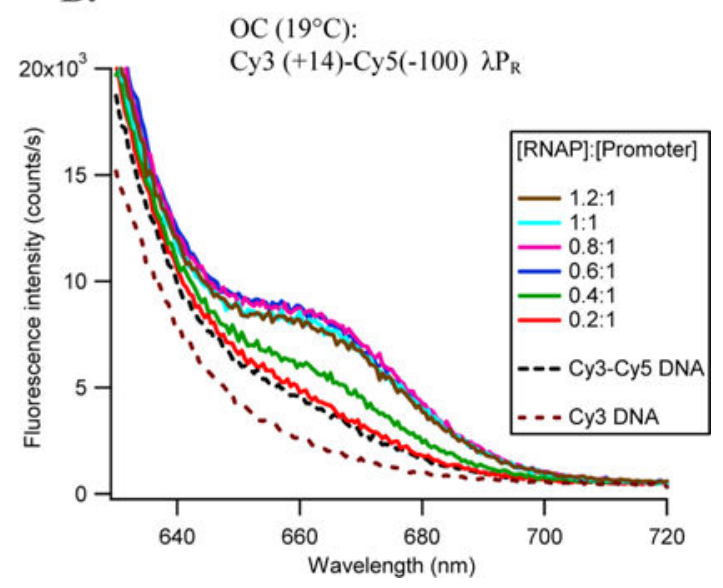

Figure 2.

Donor (Cy3) to acceptor (Cy5) fluorescence energy transfer (FRET) demonstrating wrapping in OC. Cy5 fluorescence emission spectra $(620-720 \mathrm{~nm}$; counts per second) obtained by excitation of $\mathrm{Cy} 3$ at $515 \mathrm{~nm}$ as a function of RNAP:promoter DNA concentration ratio $\left(0-1.2: 1 ; 100 \mathrm{nM}\right.$ DNA) for open $\left(\mathrm{OC} ; 19^{\circ} \mathrm{C}\right) \mathrm{RNAP}-\lambda \mathrm{P}_{\mathrm{R}}$ promoter DNA complexes: (A) Cy3(-100)-Cy5(+14) $\lambda \mathrm{P}_{\mathrm{R}}$ DNA and (B) Cy3(+14)-Cy5(-100) $\lambda \mathrm{P}_{\mathrm{R}}$. DNA spectra (-RNAP) were obtained with $100 \mathrm{nM} \mathrm{Cy3-labeled} \mathrm{DNA} \mathrm{and} \mathrm{Cy3-Cy5} \mathrm{labeled}$ DNA. 


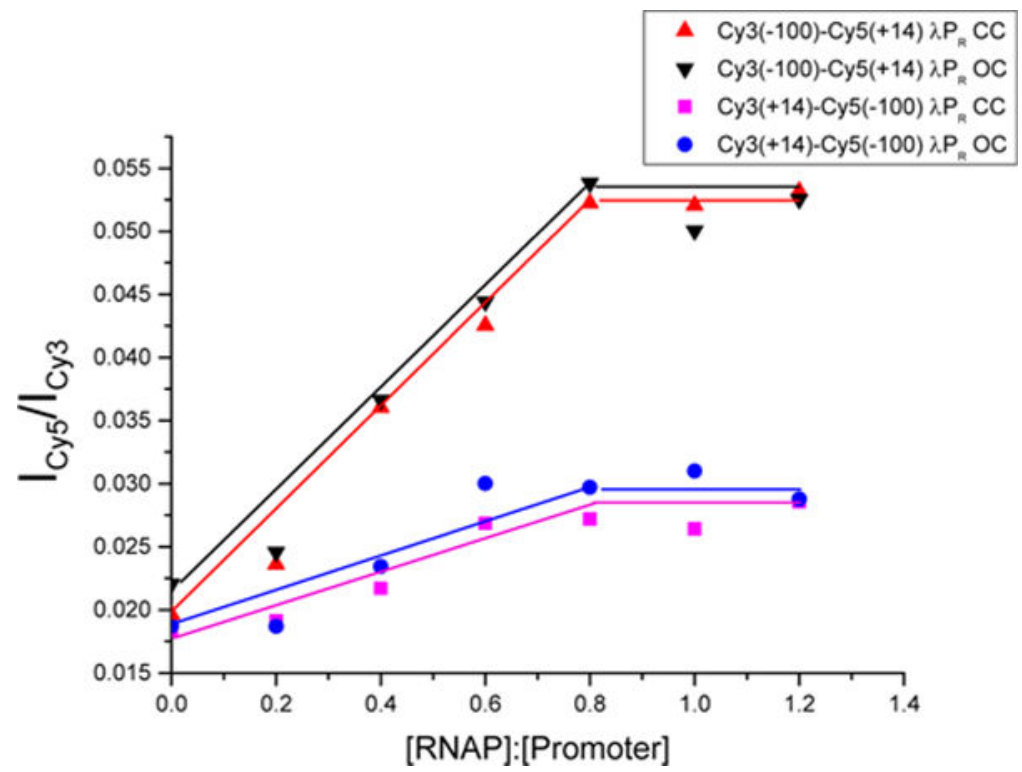

Figure 3.

Demonstration of FRET from intensity ratios $\left(I_{\mathrm{Cy} 5} / I_{\mathrm{Cy} 3}\right)$ for $\mathrm{Cy} 5$ and $\mathrm{Cy} 3$ emission at $\lambda_{\max }^{\mathrm{em}}$ upon Cy3 excitation vs RNAP:promoter DNA concentration ratio. Data for both the CC

$\left(2{ }^{\circ} \mathrm{C}\right)$ and the $\mathrm{OC}\left(19^{\circ} \mathrm{C}\right)$ of $100 \mathrm{nM}$ dye-labeled Cy3(-100)-Cy5(+14) $\lambda \mathrm{P}_{\mathrm{R}}$ and Cy3(+14)Cy5(-100) $\lambda \mathrm{P}_{\mathrm{R}}$ DNA in complex with RNAP are shown. $\lambda_{\max }^{\mathrm{em}}=660 \mathrm{~nm}(\mathrm{Cy} 5)$; $\lambda_{\max }^{\mathrm{em}}=565 \mathrm{~nm}(\mathrm{Cy} 3) . \mathrm{Cy} 3$ excitation at $515 \mathrm{~nm}$. Data are from Figures 1 and 2 . Lines interpret the FRET effect as a linear increase up to RNAP:promoter DNA concentration ratios of 0.6-0.8:1 and a plateau at higher RNAP:promoter DNA concentration ratios. 
A.
B.

$\mathrm{CC}\left(2^{\circ} \mathrm{C}\right): \mathrm{Cy} 5(+14) \lambda \mathrm{P}_{\mathrm{R}}$

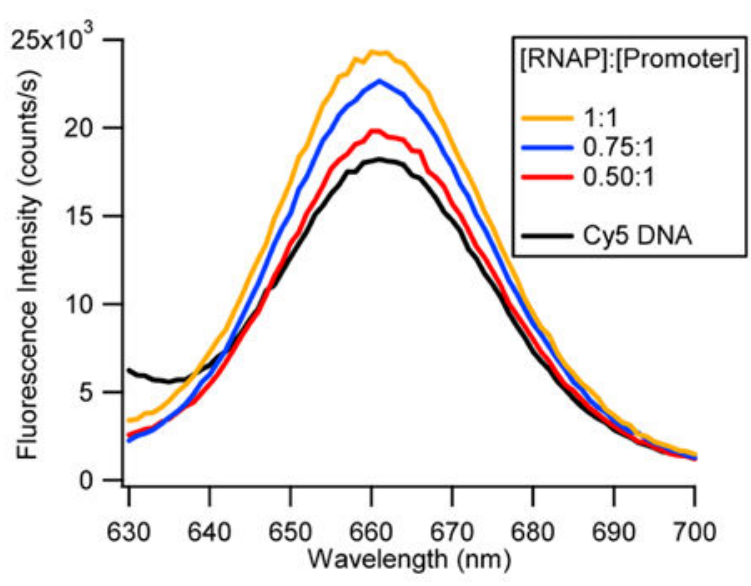

$\mathrm{OC}\left(19^{\circ} \mathrm{C}\right): \mathrm{Cy} 5(+14) \lambda \mathrm{P}_{\mathrm{R}}$

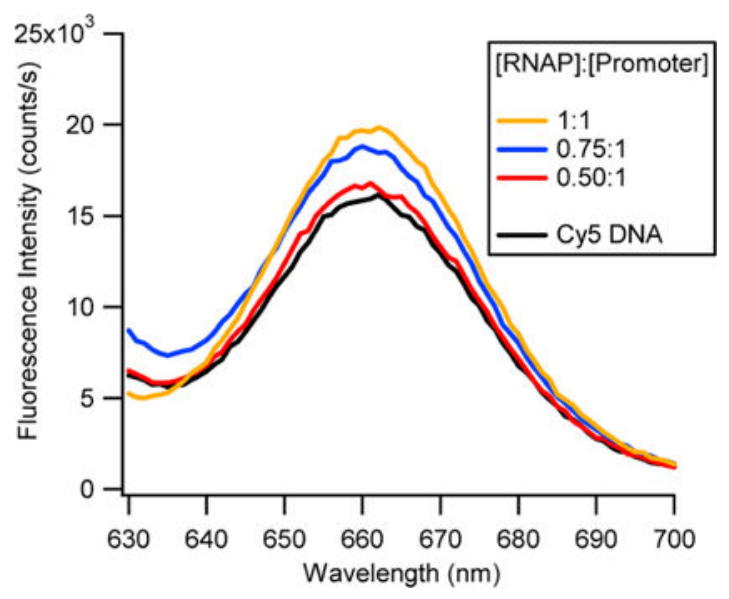

Figure 4.

Observed Cy5(+14) fluorescence enhancement (PIFE) in CC and OC: $100 \mathrm{nM} \mathrm{Cy5(+14)}$ $\lambda \mathrm{P}_{\mathrm{R}}$ promoter DNA in complex with $\operatorname{RNAP}(50,75$, and $100 \mathrm{nM})$ for the $\mathrm{CC}\left(2{ }^{\circ} \mathrm{C}\right.$; panel A) and the OC $\left(19^{\circ} \mathrm{C}\right.$; panel B). Samples were excited at $610 \mathrm{~nm}$. DNA spectra (-RNAP) were obtained with $100 \mathrm{nM}$ Cy5(+14) $\lambda \mathrm{P}_{\mathrm{R}}$ DNA. 


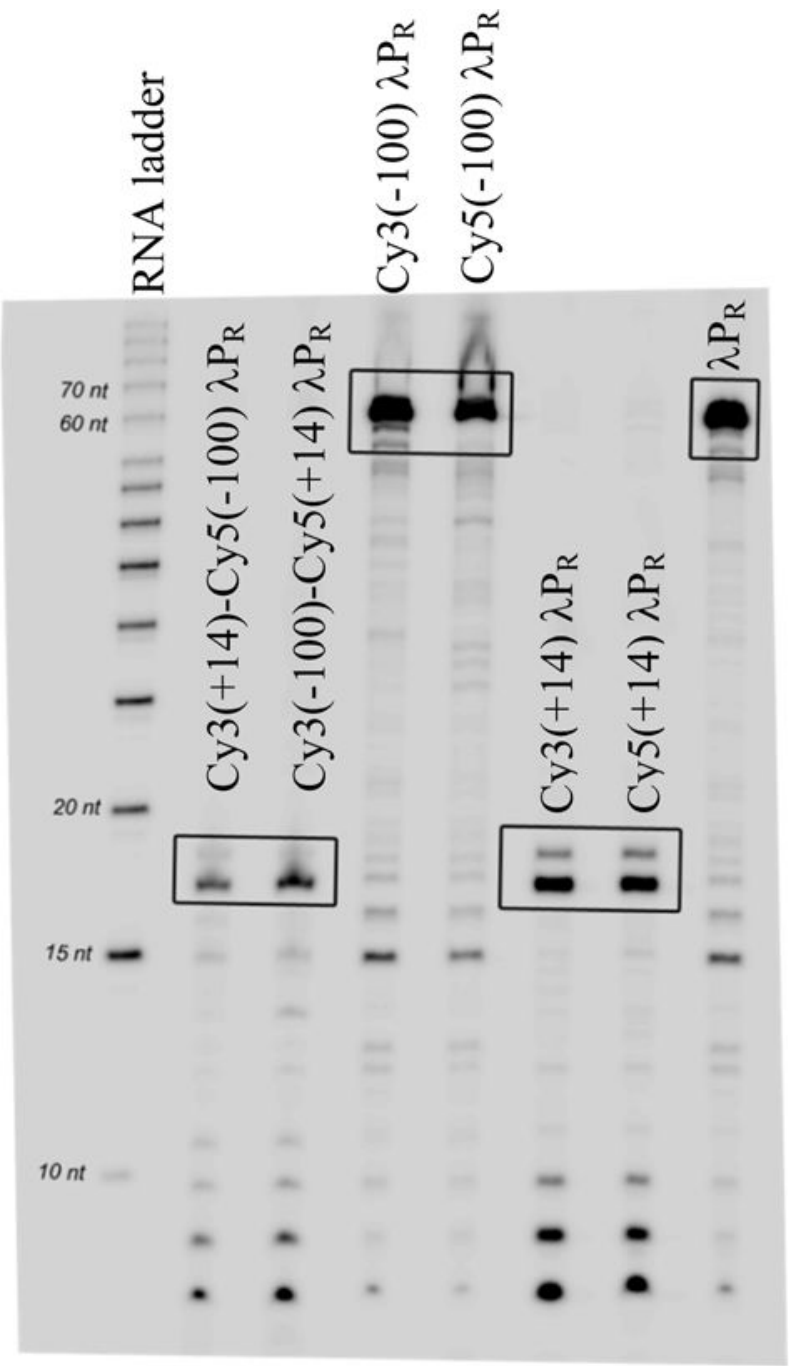

Figure 5.

Gel analysis of transcription products for two-dye (left, center), single-dye (center, right), and unlabeled $\lambda \mathrm{P}_{\mathrm{R}}$ (right lane) promoter DNA. A RNA ladder is shown at the left. Boxed areas show full-length transcripts for each fragment. 


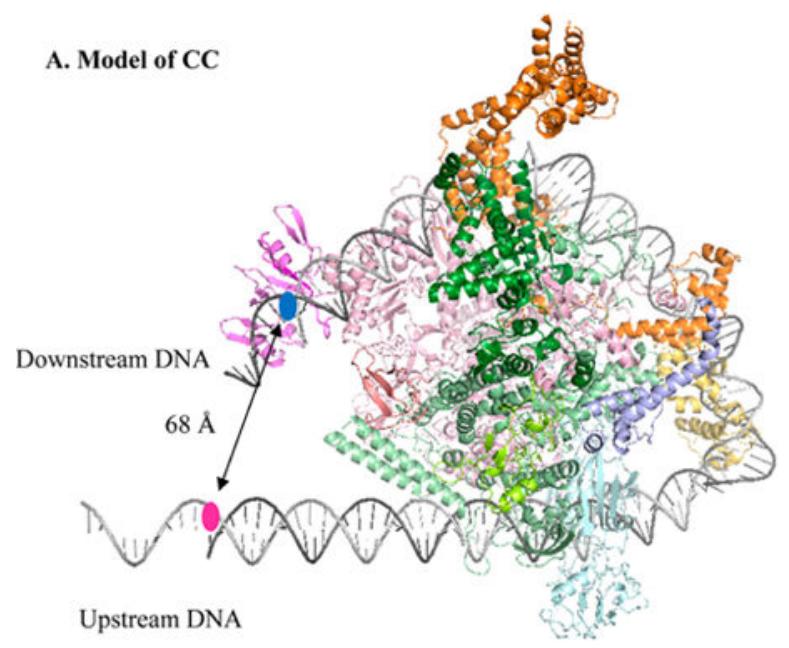

B. Model of OC

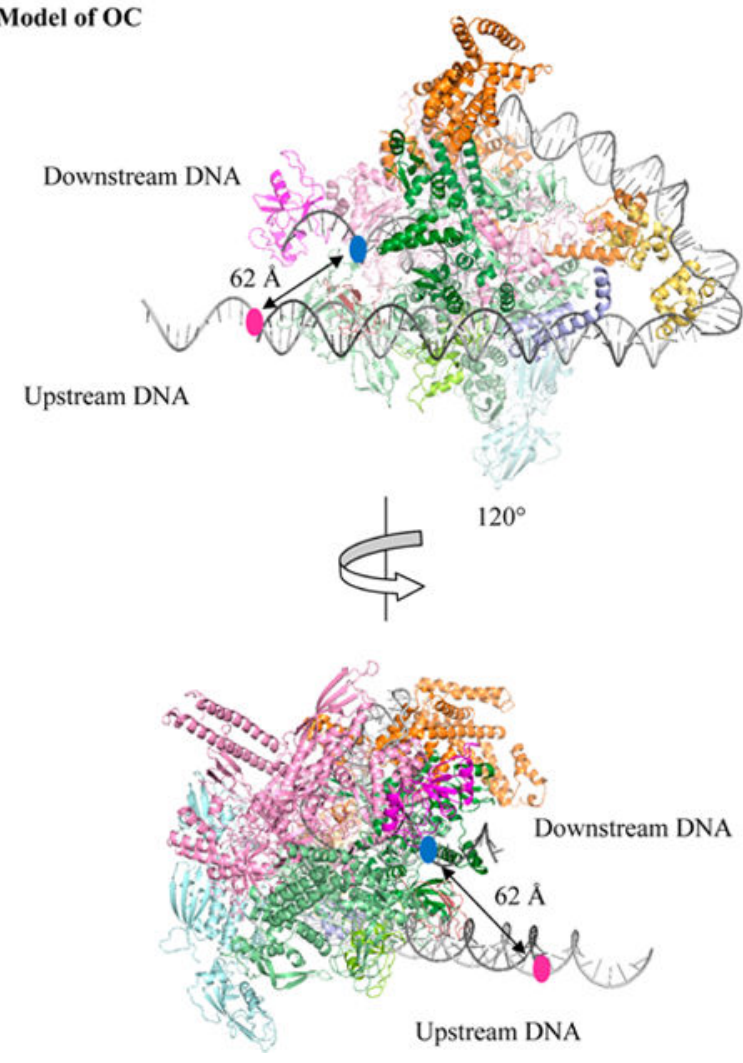

Figure 6.

Models of bent and wrapped promoter DNA in (A) CC and (B) OC with E. coli RNAP.

Models built for midrange values of the dye-dye distances, (A) $R=68 \AA$ for the $\mathrm{CC}$ and (B) $R=62 \AA$ for OC, as determined from FRET and anisotropy data (Table 1). Models based on structures of $E$. coli RNAP: PDB entry 4LJZ for the CC and PDB entry 4YLN for the OC. Cyanine dyes are shown at positions -100 (pink) and +14 (blue) as ellipsoids. RNAP subunits $a$ NTD (cyan), $a$ CTD (yellow; modeled from PDB structure 1LB2), $\beta$ (pale pink), $\beta$ (green), $\omega$ (blue), and $\sigma$ (orange) are shown. $\beta$ SI1 (dark pink, residues 225-343), $\beta$ clamp 
(dark green, residues 131-347 and 1260-1368), $\beta$ UP clamp (bright green, residues 808912), and $\beta$ jaw (brown, residues 1150-1208) are highlighted. Promoter DNA is colored light gray (nt) and dark gray (t). A "backside" view of OC is also shown in panel B. 


\section{Table 1}

FRET Efficiencies and Distances R between Promoter Positions -100 and +14 in Advanced Closed and Stable Open Complexes

\begin{tabular}{|c|c|c|}
\hline Property & Advanced Closed Complex $\left(\mathrm{CC} ; 2^{\circ} \mathrm{C}\right)$ & Stable Open Complex $\left(\mathrm{OC} ; 1^{\circ} \mathrm{C}\right)$ \\
\hline \multicolumn{3}{|l|}{ FRET efficiency $E^{a}$} \\
\hline Cy3(-100)-Cy5(+14) $\lambda \mathrm{P}_{\mathrm{R}}$ & $0.36 \pm 0.10$ & $0.36 \pm 0.14$ \\
\hline Су $3(+14)-С y 5(-100) \lambda \mathrm{P}_{\mathrm{R}}$ & $0.23 \pm 0.06$ & $0.29 \pm 0.09$ \\
\hline Average & $0.30 \pm 0.07$ & $0.32 \pm 0.11$ \\
\hline \multicolumn{3}{|c|}{ Estimates of interdye distance $R^{b}$ from FRET efficiency $E$} \\
\hline Random orientation limit $\left(\kappa^{2}=2 / 3\right)$ & $R_{2 / 3}=68 \pm 8 \AA$ & $R_{2 / 3}=62 \pm 8 \AA$ \\
\hline Anisotropy maximum $\left(\kappa_{\max }^{2}=3.59\right)$ & $R_{\max }=91 \pm 9 \AA$ & $R_{\max }=82 \pm 8 \AA$ \\
\hline Anisotropy minimum $\left(\kappa_{\min }^{2}=0.052\right)$ & $R_{\min }=47 \pm 6 \AA$ & $R_{\min }=42 \pm 4 \AA$ \\
\hline Midrange value from anisotropy & $R_{\text {mid }}=68 \pm 22 \AA$ & $R_{\text {mid }}=62 \pm 20 \AA$ \\
\hline Structural minimum value & $R_{\text {min-str }} \sim 50 \AA$ & $R_{\text {min-str }} \sim 60 \AA$ \\
\hline
\end{tabular}




\section{Table 2}

Fluorescence Anisotropies ( $r$ ) of Cyanine Dyes, Dye-Labeled DNAs, and RNAP-Promoter Complexes

\begin{tabular}{|c|c|c|}
\hline & $2{ }^{\circ} \mathrm{C}$ & $19^{\circ} \mathrm{C}$ \\
\hline Dye immobilized on DNA & 0.40 & 0.40 \\
\hline Cy3(+14) $\lambda \mathrm{P}_{\mathrm{R}}$ DNA-RNAP complex & (CC) $0.34 \pm 0.02$ & (OC) $0.36 \pm 0.01$ \\
\hline Cy3(+14) duplex $\lambda \mathrm{P}_{\mathrm{R}}$ DNA & $0.32 \pm 0.01$ & $0.31 \pm 0.01$ \\
\hline Single-stranded Cy $3(+14)$ primer & $0.28 \pm 0.01$ & $0.27 \pm 0.01$ \\
\hline Cy3 free dye & $0.24 \pm 0.02^{a, b}$ & $0.24 \pm 0.02^{a, b}$ \\
\hline Cy5(-100) $\lambda \mathrm{P}_{\mathrm{R}}$ DNA-RNAP complex & (CC) $0.33 \pm 0.03$ & (OC) $0.31 \pm 0.03$ \\
\hline Cy5(-100) duplex $\lambda \mathrm{P}_{\mathrm{R}}$ DNA & $0.32 \pm 0.02$ & $0.31 \pm 0.03$ \\
\hline Single-stranded Cy5(-100) primer & $0.29 \pm 0.02$ & $0.25 \pm 0.03$ \\
\hline Cy5 free dye & $0.17 \pm 0.04^{a, b}$ & $0.17 \pm 0.04^{a, b}$ \\
\hline
\end{tabular}

